\title{
CERCETĂRI ARHEOLOGICE PREVENTIVE ÎN AȘEZAREA \\ DIN EPOCA BRONZULUI DE LA STEJERIŞ I (JUD. CLUJ)
}

\author{
EMIL DUMITRASSCU, SORIN CLEȘIU, \\ FLORENTIN MunTEANU, RADU PETCU
}

\section{ARCHAEOLOGICAL EXCAVATIONS AT THE BRONZE AGE SETTLEMENT OF STEJERIS I (CLUJ COUNTY)}

An archaeological research was carried out at Stejeriş (Moldoveneşti commune, Cluj county) within the "Autostrada" National Research Project, during August-September 2014. As a result of the archaeological excavations four archaeological complexes were identified and investigated: two dwellings, pits and a cult construction dating to the Middle Bronze Age (Wietenberg culture). This article presents new archaeological evidence, as well as a selection of recently discovered pottery fragments, analyzed by considering the current state of research about Wietenberg culture. The archaeological site, located on Măhăceni plateau, was partially affected by the construction highway $(\mathrm{km} 64+850-65+100)$.

KEYWORDS: rescue archaeological research, Middle Bronze Age, Wietenberg culture, settlement CUVINTE CHEIE: cercetare arheologică preventivă, epoca mijlocie a bronzului, cultura Wietenberg, aşezare

\section{CONSIDERAȚII GENERALE}

Cercetările arheologice de la Stejeriș (com. Moldoveneşti, jud. Cluj) au fost realizate în cadrul Proiectului Național de Cercetare Autostrada'. Situl a fost identificat ca urmare a diagnosticului arheologic, desfasşurat în vara anului 2014 (Pl. I), realizat de către o echipă de specialişti din cadrul Muzeului Naţional de Istorie a României (MNIR),

Cercetările arheologice cu caracter preventiv, efectuate în vara-toamna anului 2014, de-a lungul a trei săptămâni, au confirmat prezenţa potenţialului arheologic semnalat anterior, fiind identificate şi investigate exhaustiv patru complexe arheologice (două locuințe de suprafață, o groapă de provizii și un complex cu (posibil) caracter de cult/ritual) ${ }^{2}$.

Obiectivele campaniei de săpături arheologice preventive au constat în identificarea și cercetarea exhaustivă a tuturor vestigiilor descoperite în perimetrul ce urmează să fie afectat de lucrările de construire a autostrăzii. De asemenea, la vest de traseul acesteia au fost identificate şi alte materiale arheologice, indicând o posibilă extindere a zonei cu potențial arheologic (PI. II).

În continuare vom prezenta rezultatele cercetării arheologice din situl Stejeriş $I^{3}$, realizate prin colaborarea echipei de arheologi din cadrul Muzeului Național de Istorie a României (MNIR) cu cei angajați la firma SC Vanderlayarheo SRL.

\footnotetext{
I În urma solicitării firmei SC PORR Construct SRL adresate Muzeului Naţional de Istorie a României, între cele două părți s-a încheiat un contract de prestări servicii în vederea efectuării cercetărilor arheologice preventive pe traseul viitoarei autostrăzi Al0 Sebeș-Turda, sector Inoc-Turda/lot 4 (km 53+700-km 70+000), în scopul întocmirii documentației necesare derulării procedurii de descărcare de sarcină arheologică, în conformitate cu cerințele legale aplicabile.

2 Cercetările au fost efectuate de către o echipă a MNIR, în baza autorizaţiei nr. 212/2014 eliberată de MC-DGJPC. Cercetarea s-a desfășurat între km 64+850 şi km 65+100 ai viitoarei autostrăzi A 10 Sebeș-Turda, sector Inoc-Turda/lot 4.

3 În campania de diagnostic arheologic, desfășurată în iunie-iulie 2014, pe tronsonul autostrăzii A10 Sebeş-Turda, sector Inoc-Turda/lot 4 au fost identificate opt situri arheologice, în cazul de fată Situl $n r .5=$ Stejeriş $l$. De asemenea, în raza administrativã a satului Stejeriş au fost identificate și delimitate douã situri, astfel cã cel de-al doilea este denumit Situl nr. $6=$ Stejeriș $I$.
} 
Satul Stejeriş aparține comunei Moldovenești, județul Cluj, situat în podișul Măhăceni. Acesta este poziționat în sudul județului menționat, imediat la nord de limita administrativă cu județul Alba. Din punctul de vedere al reperelor geografice se află relativ în apropierea confluenței Arieşului cu râul Mureș. Podișul amintit este puternic fragmentat de pâraiele Stejeriş şi Unirea (afluenți secundari ai Mureșului), ce pun în evidență un relief structural cu interfluvii bine conturate, în zonă având loc frecvente procese de alunecări și deplasări ale solului, denumite de localnici glimee ${ }^{4}$.

Podişul Măhăceni este traversat de văi largi, cu lunci colmatate, presărate cu lacuri și mlaștini. Vegetația zonei se caracterizează în prezent prin terenuri agricole și pajiști stepizate secundar în locul pădurilor de gorun, stejar, cer, gârniță, iar solurile sunt de tip regosoluri ${ }^{5}$.

Situl arheologic Stejeriș I este situat la $3,10 \mathrm{~km}$ ENE față de satul cu același nume, de care aparţine administrativ, la aproximativ $200 \mathrm{~m}$ vest față de DN 1, la $670 \mathrm{~m} \mathrm{~N}$ față de lacul Stejeriş și a 1,25 km S față de lacul Bădeni (Pl. I/b). Este poziționat pe partea dreaptă a pârâului Unirea, la aproximativ $150 \mathrm{~m} \mathrm{E}$ de acesta, pe terasa a doua (încadrată în categoria $\mathrm{E}$ ) ${ }^{6}$.

\section{SCURT ISTORIC AL CERCETĂRILOR DIN ZONA DE REFERINȚĀ}

Pe teritoriul localității Stejeriș ${ }^{7}$ au fost descoperite în diferite puncte materiale de interes arheologic. Astfel, în punctul Izvorul Rece poziţionat la marginea satului, în anul 1987 au fost identificate fragmente ceramice neolitice (culturile Starcevo-Criș şi Petrești), de tranziție către epoca bronzului (cultura Coțofeni), din epoca bronzului (cultura Wietenberg), hallstattiene, dacice şi din secolele IX-XI p. Chr. În zona Gâlmee, ce desparte valea Stejărișului de Măhăceni, sunt semnalați o serie de tumuli; tot în zonă s-au descoperit (în arătură) fragmente ceramice din epoca bronzului. Lângă pârâul, în punctul Vizuina Lupului au fost identificate resturi osteologice umane, o sabie de fier din secolul al XII-lea, bucăți de fier și lemn. De asemenea, de pe teritoriul satului, fără precizarea locului de descoperire, provine un depozit de bronzuri compus din două celturi, două brățări și o seceră, aparținând seriei Uriu-Domăneşti ${ }^{8}$, precum și monede romane.

De menționat că în raza administrativă a localității Stejeriş sunt înregistrate siturile arheologice Stejeriș-Izvoru Rece (cod LMI CJ-CJ-I-s-B-07183 ${ }^{9}$, cod RAN 58785.01) și StejerișGâlmeie (cod LMI CJ-I-s-B-07184 ${ }^{10}$, cod RAN 58785.02).

Din cele cunoscute până în momentul de față, în general, pe teritoriul României, siturile cu ceramică de tip Wietenberg sunt amplasate în interiorul arcului carpatic ${ }^{11}$, pe anumite forme de relief dominante. Situl de față reprezintă o limită a așezării situată pe terasele superioare ale pârâului Unirea. Complexele identificate se află la limita inferioară a acestuia. Cercetările arheologice efectuate aici au pus în evidență un singur nivel de locuire ${ }^{12}$ (vezi mai jos stratigrafia), cu spațiul de amenajare a locuințelor nefortificat, trăsătură definitorie a așezărilor de tip Wietenberg ${ }^{13}$.

\footnotetext{
${ }^{4}$ Negucioiu, Teodor, Edroiu 1980, 14 fig. 1,18

${ }^{5}$ Morariu, Bogdan, Maier 1980, 34, 59, 75 fig. 15, 79 fig. 16; vezi și Negucioiu, Teodor, Edroiu 1980, 34-35, fig 6.

${ }^{6}$ Rotea 1993, 36, 29 PI. II; Popa, Simina 2004, 18

${ }^{7}$ Rep CJ 1992, 369 (cu bibliografia mai veche)

${ }^{8}$ Petrescu-Dímbovița 1977, 151

${ }^{9}$ LMI 2010, 776, nr. 570

${ }^{10}$ LMI 2010, 776, nr. 574

${ }^{11}$ Motzoi-Chicideanu 2011, 527. Există însă și situri arheologice din afara arcului carpatic: poate cel mai cunoscut este cel de la Derşida (jud. Sălaj), vezi Chidioşan 1980, sau în afara ariei cunoscute cum ar fi cel din Câmpia de Vest de la Palota (jud. Bihor), vezi Emödi 2002, 5-35. Sinteze cu privire la descoperirile de tip Wietenberg: Horedt 1960, 107137; Chidioşan 1980, 7-10; Boroffka 1994, 11-92; Motzoi-Chicideanu 2011, 564-598.

${ }^{12}$ Chidioșan 1980 14; Rotea 1993, 34; Vulpe 2001, 255

${ }^{13}$ Chidioșan 1980 15; Rotea 1993, 38; Motzoi-Chicideanu 2011, 526-546
} 
Locuințele de suprafață de mari dimensiuni și amenajarea de cult/rituală ce au fost cercetate în situl Stejeriș I, aduc informații noi despre aceste comunități. De altfel, în zona Transilvaniei, pe valea Mureșului au fost identificate recent și alte noi situri ${ }^{14}$.

\section{CONSIDERAȚII DE ORDIN METODOLOGIC}

Având în vedere natura şi caracteristicile sitului, metodologia de lucru a fost adaptată şi structurată pentru trei faze principale: faza de documentare (evaluare teoretică), faza de evaluare de teren (diagnostic arheologic) și cea de cercetare de teren propriu-zisă (săpătură arheologică preventivă).

Colectivul de arheologi a fost coordonat de dr. Paul Damian în calitate de responsabil ştiințific, echipa din teren fiind alcătuită din dr. Emil Dumitrașcu, dr. Sorin Cleșiu, dr. Florentin Munteanu şi Radu Petcu.

Săpătura arheologică a început prin trasarea de secțiuni în partea nordică a sitului, în vederea delimitării sale în această direcție. De asemenea au fost trasate și suprafețe arheologice, în zona centrală, în general având $30 \times 15 \mathrm{~m}$, în vederea identificării şi cercetării complexelor arheologice. Un număr de cinci suprafețe au fost localizate în zona de strict interes arheologic (S. 004-S. 006 și S. 010-S. 011). Celelalte secţiuni (S. 001-S. 003, S. 007-S. 009, S. 012-S. 015, S. 017-S. 026), precum și o altă suprafață (S. 016), au fost deschise pentru verificarea situației în întreaga zonă cuprinsă între $\mathrm{km} 64+850-65+100$. În aceste unități de săpătură nu s-au descoperit vestigii arheologice. În urma acestor investigaţii putem afirma că autostrada a afectat limita estică a unei așezări din epoca bronzului mijlociu, aparținând ariei culturale Wietenberg (PI. III).

În funcţie de situaţiile înregistrate s-a utilizat decaparea cu mijloace mecanice (buldoexcavator cu lamă de taluz), dar şi săparea manuală. Complexele arheologice s-au săpat manual, cu efectuarea constantă a observaţiilor şi înregistrărilor de referință.

\section{STRATIGRAFIA GENERALĂ A SITULUI}

Pentru a avea o imagine cât mai sugestivă asupra stratigrafiei generale a sitului de la Stejeriș $I$, strategia iniţială a inclus trasarea de suprafețe de aproximativ $30 \times 15 \mathrm{~m}$, amplasate pe a doua terasă a pârâului Unirea, între km $64+900-65+000$, aşadar zona situată la vest de axul central al autostrăzii și de secțiuni, deschise pe prima terasă a pârâului, între aceiași kilometri. De asemenea, a fost sondată şi zona dintre $\mathrm{km} 64+850-64+900$ și $65+000-65+100$, în general prin secțiuni.

Astfel, la nivel general, a fost stabilită următoarea succesiune stratigrafică în cazul sitului Stejeriș I (PI. IX; PI. X).

- strat de sedimente de culoare gri-închis (negricios), afânat, conține resturi vegetale, pigmenți de chirpici ars și rare fragmente ceramice antrenate, reprezentând stratul vegetal, situat de la nivelul de călcare actual $(0)$, până la cota ce variază între $0,27 / 0,38 \mathrm{~m}$;

- strat de sedimente de culoare neagră, lutos, cu material ceramic şi chirpici în compoziție, situat de la cota la care se termină nivelul de arătură $(-0,27 / 0,38 \mathrm{~m})$, până la cote ce variază între $-0,50 / 0,90 \mathrm{~m}$ în partea de nord a sitului (respectiv zona complexelor 1 şi 2 ) și până la $-1,30 / 1,50 \mathrm{~m}$ în partea de sud a sitului (zona complexului 3);

- strat de sediment de culoare galben-brun, lutos, fără urme de intervenţie antropică, de la cota la care se termină nivelul precedent, $-0,50 / 1,50 \mathrm{~m}$, până la cote ce variază între $-1,28 / 1,60 \mathrm{~m}$;

\footnotetext{
${ }^{14}$ Bălan et alii $2014,215-240$
} 
- strat de sediment de culoare galbenă, lutos, cu incluziuni calcaroase, fără urme de intervenție antropică.

Podișul Măhăceni este caracterizat prin frecvente alunecări de teren ${ }^{15}$. Acest lucru a fost observat și în partea de sud a sitului Stejeriș $I$, unde viiturile și alunecările de teren au determinat anumite perturbații geologice. De asemenea, pe direcția vest-est, pe cursul pantei, spre valea pârâului Unirea, laturile de est ale celor două locuințe (complexele 2 și 3 ), au fost identificate la adâncimi mai mici, de la actualul nivel de călcare, față de laturile de nord ale acestora.

Complexele arheologice aparţin unui singur nivel de locuire, datat (pe baza ceramicii de tip Wietenberg), în perioada mijlocie a epocii bronzului. Considerând cele peste 400 de situri arheologice de acest fel cunoscute, în majoritatea cazurilor nivelul de locuire nu este reprezentat de o depunere arheologică semnificativă, o explicație fiind modul de viață al acestor comunități axat pe creșterea animalelor și mobilitatea în teren ${ }^{16}$.

\section{SCURTÃ DESCRIERE A COMPLEXELOR ARHEOLOGICE}

\section{Complexul 1. Amenajare de cult/rituală (PI. IV/1; PI. XI-XII)}

Amenajare (complexul 1), ce a fost identificată în S. 004 (carourile 2-15/B-I) și în S. 010. Complexul constă dintr-o groapă (G1), de formă circulară, încadrată de alte cinci gropi (G2-G6), de dimensiuni mai mici, cuprinse între $0,30-0,40 \mathrm{~m}$. Groapa din centru a fost practicată într-un sediment lutos de culoare galben-brună. Adâncimea la care a fost identificată groapa este de $0,60 \mathrm{~m}$ de la actualul nivel de călcare, iar adâncimea maximă este de $0,90 \mathrm{~m}$. Diametrul este de aproximativ $1 \mathrm{~m}$ (Pl. V/2,3; PI. XI-XII). Materialul arheologic descoperit în umplutura gropii este reprezentat de ceramică: fragmente ale unor vase de mari dimensiuni, decorate cu triunghiuri incizate şi decor spiralic (PI. XVIII/1-2, XIX), cești cu toarta supraînălțată cu decor canelat (PI. XXI/18), chirpici (lipitură de pereți sau vetre) şi o greutate de lut (PI. XVIII/4; PI. XXI/21). Spațiul amenajării era delimitat de trei pietre de mari dimensiuni (notate convențional P1-P3), aflate în poziție secundară, așezate aproximativ în funcţie de punctele cardinale (N, E și V); numai în cazul celei plasate spre nord (P1) a fost identificată groapa de implantare. (Pl. IV/2; Pl. XI)

Acestea au fost notate convențional cu litera „P”, poziţia lor iniţială fiind verticală şi delimitând o amenajare de cult / rituală ${ }^{17}$, după cum urmează:

- $\quad P 1$ (S. 010) - piatra din zona de nord, de mari dimensiuni $\left(L_{\text {păstrală }}=1,23 \mathrm{~m}, 1_{\text {păstrałă }}\right.$ $=0,56 \mathrm{~m})$, fragmentară $(\mathbf{P l}$. IV/3; PI. XI); Groapa de implantare a acesteia $(\mathrm{G} 7)$ avea dimensiunile: $\mathrm{D}=1,06 \mathrm{~m}, \mathrm{ad}=0,32 \mathrm{~m}$;

- P2 - piatra din zona de vest (,,menhirul” întreg), tot de dimensiuni mari ( $L=1,82$ $\mathrm{m}, \mathrm{l}=0,85 \mathrm{~m})(\mathbf{P l} . \mathbf{I V} / 4)$;

- $\quad$ P3 - piatra din zona de sud-est, fragmentară $\left(\mathrm{L}_{\text {pãstratăă }}=1,30 \mathrm{~m}, \mathrm{l}_{\text {păstralăa }}=0,35 \mathrm{~m}\right)(\mathbf{P I}$. IV/5).

\section{Complexul 2. Locuință de suprafață (PI. VI; PI. XIII)}

Locuință de suprafață (complexul 2) situată în S. 005, carourile 1-5/G-J (PI. VI/1-2) era de formă dreptunghiulară, orientată aproximativ N-S. Adâncimea la conturare era de $0,90 \mathrm{~m}$, de la nivelul actual de călcare, iar adâncimea maximă de 1,60 m (cota inferioară a gropii de par din colțul de SV). Dimensiunile generale ale complexului: lungime - 10,5 m; lățime - 7 m (PI. XIII). Modul constructiv este alcătuit dintr-o structură de pereți de chirpici cu gropi de par (şase gropi de

\footnotetext{
${ }^{15}$ Vezi supra cadrul fizico-geografic.

${ }^{16}$ Vulpe 2001, 255

17 În stadiul actual al cercetării nu au mai fost întâlnite analogii pentru amenajări de acest tip în cadrul culturii Wietenberg, iar interpretarea de față, până la alte descoperiri, reprezintă o ipoteză de lucru. Cu rezerve, am putea afirma că aceste pietre (neprelucrate ?), ar putea fi monumente megalitice de tip menhir. Acestea erau dispuse vertical sau în aliniamente caracteristice epocii neolitice şi epocii bronzului, datarea cu precizie a unor asemenea monumente fiind dificil de realizat.
} 
par identificate) și şanțuri pentru pereți. Vatra, amenajată în partea de SE a locuinței, s-a păstrat doar la nivelul amprentei termice. Dărâmătura locuinței era compusă dintr-un sediment lutos de culoare neagră ce conținea resturi de podea, fragmente ceramice, resturi de bârne arse, utilaj litic (râșnițe, lustruitoare) și chirpici vitrifiat.

\section{Complexul 3. Locuință de suprafață (PI. VII; PI. XIV)}

Locuință de suprafață (complexul 3), situată în S. 006, carourile 5-10/B-E (Pl. VII/1-3; PI. XIV), avea formă dreptunghiulară, orientată aproximativ N-S. Adâncimea la conturare era de $1,50 \mathrm{~m}$, de la nivelul actualul nivel de călcare, iar adâncimea maximă de $1,90 \mathrm{~m}$ (cota inferioară a gropii de par din colțul de NE). Dimensiunile generale ale complexului: lungime - 10,5 m; lățime $7 \mathrm{~m}$. Modul constructiv este alcătuit dintr-o structură de pereți de chirpici cu gropi de par (cinci gropi de par identificate) şi șanțuri de fundație. În partea de SE a locuinței este dispusă vatra supraînălțată de la nivelul podelei (Pl. VIII/5-7). Dărâmătura locuinței era compusă dintr-un sediment lutos de culoare neagră ce conținea fragmente ceramice, utilaj litic şi chirpici vitrifiat.

Planimetria celor două locuințe poate fi reconstituită după gropile de stâlpi și șanțurile de fundaţie pentru pereți. Planul acestora ar putea sugera construcția a două clădiri de dimensiuni mari cu acoperișul în şarpantă.

\section{Complexul 4. Groapă (PI. VIII/1-2; PI. XIII)}

Groapă situată în S. 005, caroul 6/H, în proximitatea SE a locuinței de suprafață complexul 2. Groapa a fost săpată într-un sediment lutos, de culoare galbenă, cu concrețiuni calcaroase, iar umplutura acesteia este compusă dintr-un sediment lutos de culoare neagră. Forma acesteia în plan era circulară, iar în profil cilindrică; corespunde gropilor de tip A de la Derșida (jud. Sălaj) ${ }^{18}$. Adâncimea maximă a gropii este de $0,50 \mathrm{~m}$ de la nivelul de identificare. Dimensiunile generale ale complexului: diametrul de 1,65 m. Materialul descoperit în umplutură era compus din fragmente ceramice, chirpici și un vas de provizii ars secundar, depus în poziție verticală, aproximativ în centrul gropii (PI. VIII/2; PI. XIII).

Cercetarea arheologică preventivă din situl Stejeriș $I$ a confirmat potențialul istoric şi arheologic al zonei. Pe baza descoperirilor din cadrul sitului arheologic Derşida (jud. Sălaj), aparținând culturii Wietenberg, a fost realizată o tipologie a complexelor de habitat, respectiv locuințe de tip ,semibordei” și locuințe de suprafață ${ }^{19}$. Locuințele de tip semibordei aveau o lungime maximă de $4,90 \mathrm{~m}$, iar pentru locuințele de suprafață se cunoaște o lungime maximă de 5,85 m (locuința C4/1965). Vetrele erau dispuse în interior, fără a fi sesizată o ordine sau dispunere specifice.

Pentru locuințele cercetate la Stejeriș I, denumite convenţional complexele 2 şi 3 , vetrele identificate au fost descoperite în zona de SE a acestora. Șanțul de fundație al pereților locuinței complexul 3 are o lățime de $0,30 \mathrm{~m}$. Pentru construcțiile din aşezarea de la Derşida nu au fost surprinsă o lățime mai mare de $0,15 \mathrm{~m}$.

\footnotetext{
${ }^{18}$ Chidioșan 1980, Pl. 6/2a

${ }^{19}$ Chidioșan 1980, 17-20. Locuința C4/1965 are suprafaţa cea mai mare: $25 \mathrm{mp}$. Comparativ, locuinţele de la Stejeriș 1/Sit nr. 5 au o suprafață de $73,50 \mathrm{mp}$. O situație interesantă o reprezintă descoperirea unei platforme de sediment de culoare galbenă amestecat cu pietriș, lung de $10 \mathrm{~m}$. În această amenajare a fost identificată şi groapa unui stâlp de lemn, dar deasupra nu s-a surprins nici un rest de construcţie.
} 
Materialul ceramic descoperit este constituit din tipuri de vase încadrate în faza a II-a culturii Wietenberg (cf. Chidioşan) ${ }^{20}$. Materialul este fragmentar, putând fi reconstituite o serie de forme ceramice din categoria cănilor, oalelor și străchinilor. Pasta predominantă este grosieră având ca degresant pietricele, nisip, mică. Arderea este oxidantă (portocalie, maroniudeschisă, gălbuie), sau reducătoare (culoare cenuşie, neagră). Principalele tipuri de vase ${ }^{21}$ descoperite cu ocazia acestor cercetări arheologice preventive sunt:

- oala cu decor incizat, canelat sau imprimat constituit din motive spiralice, triunghiuri haşurate, benzi, cercuri sau brâu cu alveole;

- strachina cu buza lobată, un exemplar fiind decorat sub buză prin caneluri în ghirlandă;

- castronul cu peretele în formă de „S” sau cu corp globular şi buza rotunjită, înclinată în exterior;

- cana (de mici dimensiuni) cu toarta supraînălțată decorată cu caneluri dispuse oblic sau cu buza rotunjită, înclinată în exterior, toarta inelară, decorat pe umăr cu mici alveole circulare dispuse în șir.

Majoritatea fragmentelor prezente în catalog fac parte din inventarul complexului complexul 1, materialul din cele două locuințe (complexele 2 și 3), fiind fragmentar și în curs de prelucrare.

Cercetările arheologice preventive desfășurate în perioada august-septembrie 2014 pe traseul viitoarei autostrăzi A 10. Sebeș-Turda, în zona localității Stejeriș, au condus la cercetarea exhaustivă a celor patru complexe identificate: două locuințe de suprafață, o amenajare de cult/rituală și o groapă menajeră.

Încadrarea cronologică a sitului s-a făcut pe baza studiului materialului arheologic (ceramică de tip Wietenberg), în perioada mijlocie a epocii bronzului. Ceramica, utilajul litic, materialul osteologic animal și fragmentele de pereți din chirpici reprezintă artefactele descoperite în locuințe, zona de cult și groapa de provizii. Importanța săpăturii este dată de cercetarea a două locuințe de mari dimensiuni și a unei posibile amenajări de cult/rituală; prin dimensiunile lor, cele două locuințe fac notă distinctă în raport cu alte structuri de habitat identificate anterior în aria de răspândire a culturii Wietenberg. La vest de porțiunea investigată din situl arheologic Stejeriș $I$, ca urmare a unor periegheze (efectuate în toamna anului 2014), au fost prelevate și alte materiale arheologice, ceea ce indică o nouă zonă de interes arheologic, care ar putea aduce noi informații despre structurile de habitat preistorice din acest micro-areal geografic.

\footnotetext{
${ }^{20}$ Chidioșan 1980, 72-77
}

${ }^{21}$ Chidioșan 1980, 27-43 


\section{CATALOGUL DESCOPERIRILOR ${ }^{22}$}

1. Oală. $C x 1,-0,30-0,60 \mathrm{~m} ; \mathrm{D}_{\mathrm{g}}=34 \mathrm{~cm}, \mathrm{D}_{\mathrm{m}}=$ $60 \mathrm{~cm}, \mathrm{H}_{\mathrm{p}}=34 \mathrm{~cm}$. Fragmentar (se păstrează aproximativ $1 / 3$ din vas, lipsind fundul), ardere oxidantă. Corp bombat, cu pereții în formă de „S” și buza verticală. Pastă grosieră de culoare portocalie având ca degresant pietricele şi mică. Decorul este dispus în trei registre, primul este reprezentat de o bandă incizată dublã ce încadrează incizii oblice, al doilea este reprezentat de triunghiuri cu vârful în sus dispuse în bandă, triunghiuri hașurate cu linii oblice incizate în succesiune cu triunghiuri simple $^{23}$, iar al treilea este motivul spiralic realizat cu ajutorul inciziei și canelurilor ${ }^{24}$. Buza este decorată cu linii incizate dispuse oblic pe interiorul şi pe exteriorul acesteia ${ }^{25}$. Vasul prezintă două proeminențe (butoni aplicați) dispuse sub diametrul maxim. Bibl. Horedt 1960, 124-125, Abb. 12, A/1; Chidioşan 1980 I.f, Pl. 9/5; Boroffka 1994, 131, oală cu profilul în S (Topf mit S-profil), tip TA4e. Notă: Fragmentele ceramice au fost depuse în groapă alcătuind un pat de cioburi, iar vasul prezintă urme de ardere secundară. PI. XIX/1

2. Oală. $C x \quad 1,-0,60 \mathrm{~m} ; \mathrm{D}_{\mathrm{g}}=20 \mathrm{~cm}, \mathrm{D}_{\mathrm{m}}=25$ $\mathrm{cm}, H_{p}=13 \mathrm{~cm}$. Fragmentar (se păstrează unul din pereții corpului), ardere oxidantă. Corp bombat în zona diametrului maxim, cu peretele vasului în formă de $\mathrm{S}$, gâtul drept, cilindric, buza dreaptă, uşor evazată. Pastă fină de culoare portocalie având ca degresant pietricele și mica. Decorul alcătuit din cercuri imprimate este dispus în benzi orizontale sub buză și deasupra diametrului maxim ${ }^{26}$. Decorul spiralic canelat este dispus în jumătatea inferioară a corpului sub banda de cercuri în şir orizontal. Buza este decorată pe margine cu incizii oblice. Bibl. Horedt 1960, 124-125, Abb. 12, A/2; Chidioşan 1980 I.f, PI. 11/6; Boroffka 1994, 131, oală cu profilul în $\mathrm{S}$ (Topf mit S-profil), tip TA4e. PI. $\mathbf{X I X} / \mathbf{2}$

\footnotetext{
${ }^{22}$ Organizarea catalogului: numărul curent; categorie obiect (formă vas, grup funcţional); context arheologic; dimensiunile şi starea de conservare a obiectului; descriere morfologică; decor; analogii; referinţe bibliografice; datare; note şi observaţii, ilustrație. Abrevieri folosite în catalog: $C x-$ complex arheologic; m - metri; $L c$ - locuinţă; Notă - observaţii; Bibl. - referinte bibliografice, analogii; $\mathrm{L}=$ lungime; 1 = lățime; $H_{p}=$ înălțimea păstrată; $\mathrm{D}_{\mathrm{g}}=$ diametrul gurii; $\mathrm{D}_{\mathrm{m}}=$ diametrul maxim; Pl. - planșă.

${ }^{23}$ Boroffka1994, Teil 2, Pl. I5/VD 18

${ }^{24}$ Boroffkal994, Teil 2, Pl. 22, VA 16

${ }^{25}$ Boroffka 1994, 182, 189, 190, Pl. 17/VD 44

${ }^{26}$ Boroffka 1994, 188, Pl. 12/tip VD4
}

3. Oală. $C x 2(L c .1),-0,15-0,20 \mathrm{~m}, \mathrm{D}_{\mathrm{g}}=16 \mathrm{~cm}$. Fragmentar (se păstrează un fragment din buză), ardere oxidantă. Buza dreaptā, rotunjită. Pastă grosieră de culoare maroniu-deschisă, având ca degresant pietricele și mică. Brâu cu alveole imprimate pe buză și imediat sub aceasta. Bibl. Horedt 1960, 124-125, Abb. 12, A/4; Chidioșan 1980 I.c, Pl. 8/6. Pl. XX/3

4. Oală. $C x 2(L c .1),-0,15-0,20 \mathrm{~m}, \mathrm{D}_{\mathrm{g}}=22,5$ $\mathrm{cm}$. Fragmentar (se păstrează un fragment din buză), ardere oxidantă. Buza dreaptă uşor înclinată spre exterior, rotunjită. Pastă grosieră de culoare gălbuie având ca degresant pietricele și mică. Brâu cu alveole dispus sub buză (Borofka 1994, 192, VE4). Bibl. Horedt 1960, 124-125, Abb. 12, A/4; Popa, Simina 2004, 168, Pl. 6/5. Boroffka 1994, 122-124, tip TA2. PI. XX/4

5. Oală. $C x 2(L c .1),-0,15-0,20 \mathrm{~m}, \mathrm{D}_{\mathrm{g}}=28 \mathrm{~cm}$. Fragmentar (se păstrează un fragment din buză şi toarta inelară), ardere oxidantă. Buza este uşor evazată, rotunjită la exterior. Pastă grosieră, de culoare portocalie, având ca degresant pietricele şi mică. Buza vasului decorată cu brâu alveolar (Boroffka 1994, 192, VE4). Bibl. Horedt 1960, 124-125, Abb. 12, A/4; Chidioşan 1980 I.b, Pl. 8/4; Popa, Simina 2004, 167, Pl. 5/2; Boroffka 1994, 122-124, tip TA2. PI. XX/5

6. Strachină. $C x \quad 1,-0,30-0,60 \mathrm{~m} ; D_{\mathrm{g}}=36 \mathrm{~cm}$. Fragmentar (se păstrează un fragment cu toarta prinsă de buză), ardere oxidantă. Buza este dreaptă, rotunjită. Pastă grosieră, de culoare portocalie, având ca degresant pietricele şi mică. Brâu cu alveole pe buză și pe umărul vasului (Boroffka 1994, 192, VE4). Bibl. Horedt 1960, 124-125, Abb. 12, A/4; Boroffka 1994, 122 124, tip TA2. PI. XX/6

7. Strachină. $C x 2(L c .1),-0,15-0,20 \mathrm{~m} ; \mathrm{D}_{\mathrm{g}}=$ $30 \mathrm{~cm}$. Fragmentar (se păstrează un fragment buză), ardere oxidantă. Buza subțiată, uşor înclinată spre exterior, rotunjită. Pastă grosieră, de culoare portocalie, având ca degresant pietricele și mică. Vasul este decorat pe buză cu un brâu cu incizii oblice (Boroffka 1994, 192, VE7). Bibl. Horedt 1960, 124-125, Abb. 12, A/4; Chidioșan 1980 I.b, Pl. 8/4. Boroffka 1994, 122-124, tip TA2. PI. XX/7

8. Oală. $C x \quad 1,-0,60 \mathrm{~m} ; D g=14 \mathrm{~cm}$. Fragmentar (se păstrează un fragment din buză și toarta inelară), ardere oxidantă. Buza rotunjită la exterior. Pastă grosieră, de culoare gălbuie, având ca degresant pietricele și mică. Vasul este nedecorat. Fragmentul păstrează o toartă inelară aplicată sub buză (Boroffka 1994, 118 poziție toartă 2 și 3). Bibl. Horedt 1960, 124-125, Abb. 12, A/10; Chidioșan 1968, 171, Abb. 12, II/4; Chidioşan 1980 I.d, Pl. 9/2 Boroffka 1994, 122 124, tip TA2. PI. XX/8 
9. Oală. $C x 2(L c .1),-0,15-0,20 \mathrm{~m}, \mathrm{D}_{\mathrm{g}}=24 \mathrm{~cm}$. Fragmentar (se păstrează un fragment din buză şi corp), ardere oxidantă. Corpul este bombat, buza este dreaptă, rotunjită la exterior. Pastă grosieră, de culoare cenuşiu-gălbuie, având ca degresant pietricele şi mică. Vasul este nedecorat. Bibl. Boroffka 1994, 122-124, tip TA2. PI. XX/9

10. Oală. $C x 2(L c .1),-0,15-0,20 \mathrm{~m} ; \mathrm{D}_{\mathrm{g}}=24$ $\mathrm{cm}$. Fragmentar (se păstrează un fragment buză cu toarta prinsă de aceasta, similară nr. cat. 8 , vezi mai sus), ardere oxidantă. Buza este evazată, toarta inelară fiind prinsă de aceasta. Pastă grosieră, de culoare portocalie, având ca degresant pietricele şi mică. Vasul este nedecorat. Bibl. Horedt 1960, 124-125, Abb. 12, D/3; Chidioşan 1968, 171, Abb. 12, II/4; Chidioşan 1980 I.d, Pl. 9/2; Boroffka 1994, 122-124, tip TA2. Pl. XX/10

11. Oală. $C x 2(L c .1),-0,15-0,20 \mathrm{~m}, \mathrm{D}_{\mathrm{g}}=14$ $\mathrm{cm}$. Fragmentar (se păstrează un fragment cu toarta prinsă de buză, la fel ca nr. 8 din catalog) ardere oxidantă. Buza dreaptă cu toarta inelară prinsă de aceasta. Pastă grosieră, de culoare gălbuie, având ca degresant pietricele și mică. Vasul este nedecorat. Bibl. Horedt 1960, 124125, Abb. 12, D/3; Boroffka 1994, 122-124, tip TA2. PI. XX/11

12. Oală. $C x 1,-0,30-0,60 \mathrm{~m}, \mathrm{D}_{\mathrm{g}}=16 \mathrm{~cm}$. Fragmentar (se păstrează un fragment din buză cu toarta aplicată, similar nr. cat. 8, vezi mai sus), ardere oxidantă. Buza este uşor înclinată spre exterior, cu toarta inelară prinsă e aceasta. Pastă grosieră, de culoare gălbuie, având ca degresant pietricele şi mică. Vasul este nedecorat. Bibl. Horedt 1960, 124-125, Abb. 12, A/10; Chidioşan 1968, 171, Abb. 12, II/4; Chidioșan 1980 I.d, Pl. 9/2; Boroffka 1994, 122-124, tip TA2. PI. XX/12

13. Castron. $C x \quad 1,-0,30-0,60 \mathrm{~m} ; D_{\mathrm{g}}=14 \mathrm{~cm}$. Fragmentar (se păstrează un fragment din buză şi corp), ardere oxidantă. Corp globular, profil în formă de „S”, buza uşor înclinată spre exterior. Pastã grosieră, de culoare portocalie, având ca degresant pietricele şi mică. Vasul este nedecorat. Bibl. Horedt 1960, 124-125, Abb. 12, E/3; Chidioşan 1980 IV, Pl. 10/9; Boroffka 1994, 144-145, tip TD2. PI. XXI/13

14. Castron. $C x 1,-0,30-0,60 \mathrm{~m} ; \mathrm{Dg}=13 \mathrm{~cm}$. Fragmentar (se păstreazã aproximativ 1/3 din vas) ardere oxidantă. Corpul este globular, iar buza rotunjită, înclinată în exterior. Pastă grosieră, de culoare portocalie, având ca degresant pietricele şi mică. Vasul este nedecorat. Bibl. Horedt 1960, 124-125, Abb. 12, K/15; Chidioșan 1968, 171, Abb. 12, II/3; Berecki, Balasz 2007, 222-223, Pl. 2/4, pl. 3/4; Boroffka 1994, 147-148, tip TD3e. PI. XXI/14 15. Strachină (Zipfelschüsssel). Cx 2 (Lc.1), $0,15-0,20 \mathrm{~m} ; D_{\mathrm{g}}=28 \mathrm{~cm}$. Fragmentar (se păstrează un fragment din buză), ardere oxidantă. Buza vasului este rotunjită, iar gura vasului este cvadrilobată. Pastă fină, de culoare gălbuie, având ca degresant nisip, pietricele şi mică. Vasul este nedecorat. Bibl. Horedt 1960, 124-125, Abb. 12, K/15; Chidioşan 1968, 171, Abb. 12, II/3; Chidioşan 1980 H.4, Pl. 21/9; Boroffka 1994, 154-158, tip TE1, TE2. PI. XXI/15

16. Strachină (Zipfelschüsssel). Cx 3 (Lc. 2), $0,30-0,40 \mathrm{~m}, \mathrm{D}_{\mathrm{g}}=24 \mathrm{~cm}$. Fragmentar (se păstrează un fragment din buză), ardere reducătoare. Buza vasului este rotunjită, iar gura vasului este cvadrilobatã. Pastă finã, de culoare cenuşie, având ca degresant nisip, pietricele și mică. Vasul este decorat sub buză cu caneluri în ghirlandă. Bibl. Horedt 1960, 124-125, Abb. 12, K/13; Chidioşan 1980 H.4, Pl. 21/9; Boroffka 1994, 154-158, TE1, TE2. PI. XXI/16

17. Ceaşcă. $C x \quad 1,-0,30-0,60 \mathrm{~m} ; D g .8 \mathrm{~cm}$. Fragmentar (se păstrează un fragment din buză), ardere oxidantă. Buza este rotunjită, ușor înclinată. Pastă fină, de culoare portocalie, având ca degresant pietricele, nisip și mică. Vasul este decorat cu caneluri dispuse oblic. Bibl. Horedt 1960, 124-125, Abb. 12, E/5; Bălan et alii 2014, 238, Pl. 11/5. Notă. Toarta inelară supraînălțată nu se mai păstrează, fragmentul prezintã urme de ardere secundară. PI. XXI/17

18. Ceaşcă. $C x 1,-0,30-0,60 \mathrm{~m} ; \mathrm{D}_{\mathrm{g}}=10 \mathrm{~cm}$. Fragmentar (se păstrează un fragment din buză cu toarta supraînălțată aplicată), ardere oxidantă. Buza este rotunjită, uşor înclinată; toart aplicată, supraînălțată. Pastă fină, de culoare portocalie, având ca degresant pietricele, nisip și mică. Vasul este decorat cu caneluri dispuse oblic. Bibl. Horedt 1960, 124-125, Abb. 12, F/5; Chidioșan 1968, 171, Abb. 12, II/3; Chidioșan 1980 III.b, Pl. 10/7 şi G.3, Pl. 20/3; Soroceanu, Retegan 1981, 212, Abb. 4/3. Notă: Fragmentul prezintă urme de ardere secundară. $\mathbf{P I}$ XXI/18 19. Vas miniatural. $C x 1,-0,30-0,60 \mathrm{~m} ; \mathrm{D}_{\mathrm{g}}=8$ $\mathrm{cm}$. Fragmentar (se păstrează un fragment din buză și corp), ardere oxidantã. Corpul este globular, buza este rotunjită, înclinată în exterior, toarta inelară a fost aplicată imediat sub buză. Pastă grosieră, de culoare portocalie, având ca degresant pietricele şi mică. Vasul este decorat pe umăr cu mici alveole circulare dispuse inegal. Bibl. Horedt 1960, 124-125, Abb. 12, D/1; Chidioșan 1980 IV, Pl. 10/3. Notă. Vasul prezintă urme de ardere secundară. PI. XXI/19

20. Cană ? Cx 2 (Lc.1), $-0,15-0,20 \mathrm{~m} ; \mathrm{Dg}=10$ $\mathrm{cm}$. Fragmentar (se păstrează un fragment cu toarta prinsă de buză), ardere oxidantă. Buza este larg evazată, rotunjitã. Pastă grosieră, de culoare gălbuie, având ca degresant pietricele și mică. Vasul este nedecorat. Bibl. Horedt 1960, 
124-125, Abb. 12, A/6; Datare: faza a III-a. Pl. XXI/20

21. Greutate. $C x 1,-0,30-0,60 \mathrm{~m} ; \mathrm{L}=11 \mathrm{~cm}, 1$ $=8 \mathrm{~cm}$. Greutate din lut de formă tronconică cu gaură circulară de prindere. Pastă grosieră, de culoare cenușie, având ca degresant pietricele şi mică. Notă: Prezintă urme de ardere secundară. Pl. XXI/21

BIBLIOGRAFIE

Bălan et alii 2014

Berecki, Balász Áldor 2007

Boroffka 1994

Chidioşan 1968

Chidioşan 1980

Rep CJ 1992

Emödi 2002

Horedt 1960

Motzoi-Chicideanu 2011

LMI 2010

Morariu, Bogdan, Maier 1980

Negucioiu, Teodor, Edroiu 1980

Popa, Simina 2004

Rotea 1993

Soroceanu, Retegan 1981

Vulpe 2001
G. Bălan, Raluca Burlacu-Timofte, M. Râza, T. Munteanu, Situri descoperite recent aparținând culturii Wietenberg, Apulum, LI, 2014, p. $215-240$

S. Berecki, C. Balász Áldor, O așezare aparținând culturii Wietenberg de la Unirea (jud. Alba), Acta Siculica, Muzeul Naţional Secuiesc, Sfầntul Gheorghe, 2007, p. 217-223

N.G.O. Boroffka, Die Wietenberg-Kultur. Ein Beitrag zur Erforshung der Bronzezeit in Südosteuropa, Teil 1, 2, Bonn, 1994

N. Chidioşan, Beiträge zur Kenntnis der Wietenberg-kultur im liechte der neuen Funde von Derșida, Dacia N.S., 12, 1968, p. 155-175

I. Chidioșan, Contributii la istoria tracilor din nord-vestul României. Așezarea Wietenberg de la Derșida, Oradea, 1980

I. H. Crişan (coord.), M. Bărbulescu, E. Chirilă, V. Vasiliev, Iudita Winkler, Repertoriul arheologic al judetului Cluj, Cluj-Napoca, 1992

I. Emödi, O aşezare din epoca veche de la Palota veche, Eph. Nap., XII, 2002, p. 5-35

K. Horedt, Die Wietenbergkultur, Dacia N.S., IV, 1960, p. 107-137

I. Motzoi-Chicideanu, Obiceiuri funerare in epoca bronzului la Dunărea Mijlocie și Inferioară, București, 2011

Lista Monumentelor Istorice, Monitoml Oficial, partea I, nr. 670 din 1 octombrie 2010

T. Morariu, O. Bogdan, A. Maier, Județul Alba, Bucureşti, 1980

A. Negucioiu, P. Teodor, N. Edroiu, Cluj. Monografie, Bucureşti, 1980

Cr.I. Popa, M.N. Simina, Cercetări arheologice la Lancrăm - Glod, Alba Iulia, 2004

M. Rotea, Așezările culturii Wietenberg, Eph. Nap., III, 1993, p. 2541

T. Soroceanu, A. Retegan, Neue spätbronzezeitliche Funde im norden Rumänien, Dacia N.S., 25, 1981, p. 195-229

Al. Vulpe, Perioada mijlocie a epocii bronzului, în M. PetrescuDâmbovița, Al. Vulpe (ed.), Istoria Românilor, Bucureşti, 2001, p. $247-272$

\section{LIST OF ILLUSTRATION}

PI. I Stejeriş I archaeological site: 1. Geographic location (detail Google Earth); 2. General plan overlapped on ortophotomap

PI. II Stejeriş I archaeological site: 1. General excavation plan (overlapped on a Google Earth image); 2. Panoramic view of the archaeological site from the east

PI. III Stejeriş I archaeological site: General plan of archaeological excavation

PI. IV Complex 1: 1. General view from SE; 2. Detail on large stone (P1) and posthole (G7) located in S. $010 ; 3$. Detail on large stone (PI) located in S. $010 ; 4$. Detail on large stone (P2) located in S. $004 ; 5$. Detail on large stone (P3) located in S. 004

PI. V Complex 1: 1. General view from SE (initial excavation stage); 2. View from the south (detail); 3. Pottery fragments in situ (detail) 
PI. VI Complex 2 (dwelling): 1. General view from NV; 2. General view from NV during identification; 3. General view from south; 4. View from south (detail on the SV part); 5. Longitudinal profile; 6. Crosssection profile

PI. VII Complex 3 (dwelling): 1. General view from south during identification; 2. General view from south; 3. General view from SE; 4. Cross-section profile

PI. VIII Complex 4: 1. Cross-section; 2. Vessel in situ; Complex 2: 3. posthole; 4. posthole; Complex 3: 5-6. hearth; 7. hearth (cross-section)

PI. IX 1-3. S. 004 main South profile

PI. X 1. S. 004, main South profile of the excavation unit, including backfill debris of Complex 2 (surface dwelling); 2. S.005, main North profile of the excavation unit, including backfill debris of Complex 2 (surface dwelling)

Pl. XI Complex 1: Ground plan and profile of the setting up pit of large stone (Pl)

Pl. XII Complex 1: Ground plan (detail) and cross-section West profile

PI. XIII Complex 2 (surface dwelling): Ground plan, longitudinal and cross-section profile; Archaeological complex 4: Ground plan and cross-section profile of the pit located southeastwards of Complex 2

PI. XIV Complex 3 (surface dwelling): Ground plan and cross-section profile

PI. XV Complex 1: 1-3. Fragments of wall

PI. XVI Complex 2, lithic material: 1-2. Fragments of grinders; 3. Stone polish tools

PI. XVII Lithic material: 1-3. Fragments of grinding mills (Complex 2); 4. Fragment of grinding mill (Complex 4)

Pl. XVIII 1-5. Pottery fragments (photos); 6. Clay weight (photo)

PI. XIX Archaeological complex Complex 1: 1-2. Pots

PI. XX 3-12. Pots

Pl. XXI 13-14. Bowls; 15-16. Dishes (shallow bowls); 17-18. Cups; 19. Miniature vessel; 20. Jug; 21. Weight

Emil Dumitrașcu, Sorin Cleşiu, Florentin Munteanu Muzeul Naţional de Istorie a României emildumitrascuionut@gmail.com; clesiusorin@mnir.ro, florentin_m@yahoo.com

RADU PETCU

SC Vanderlayarheo SRL 


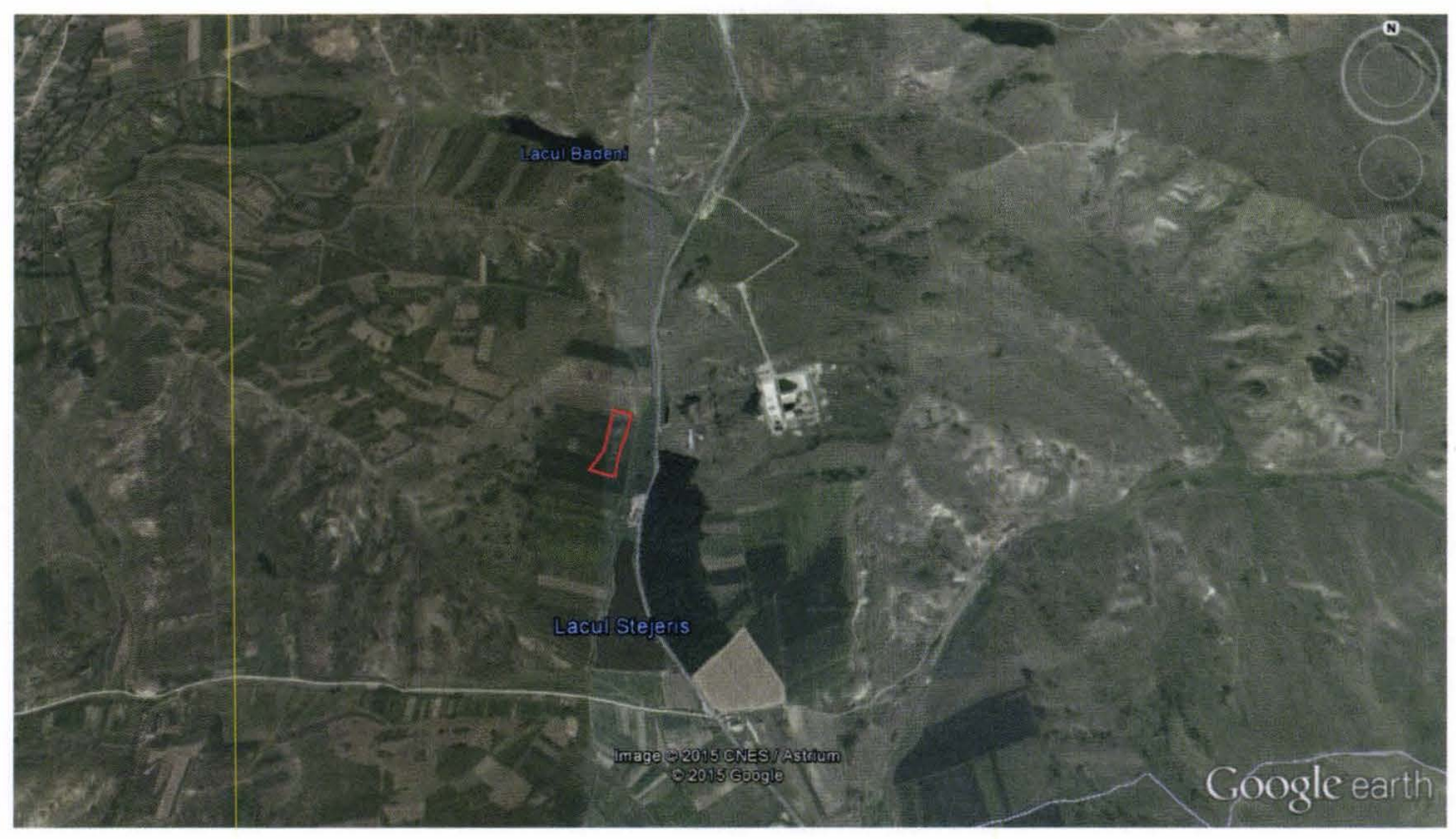

1.

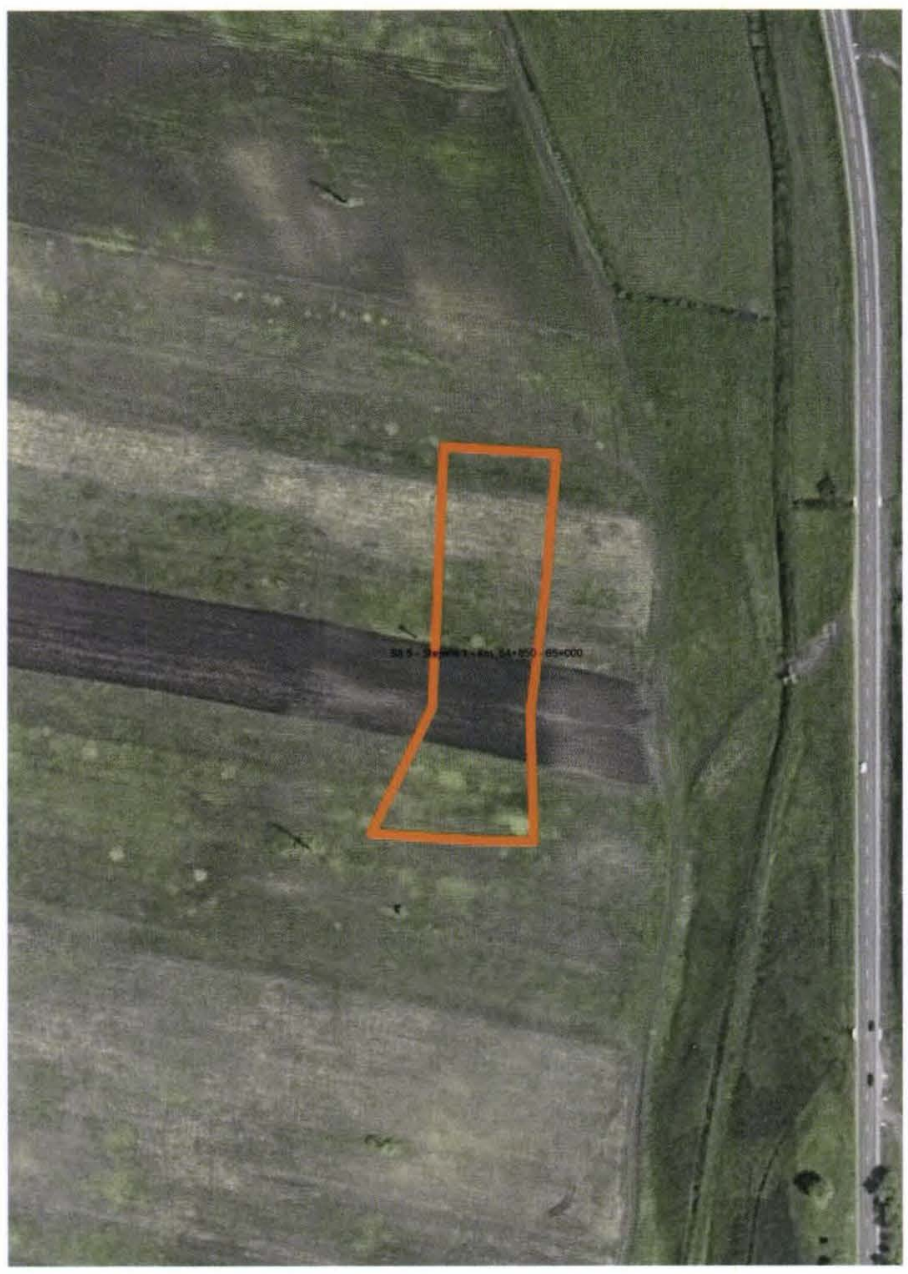

2.

Situl arheologic Stejeriș I: 1. Localizarea geografică (detaliu Google Maps); 2. Încadrare pe ortofotoplan 


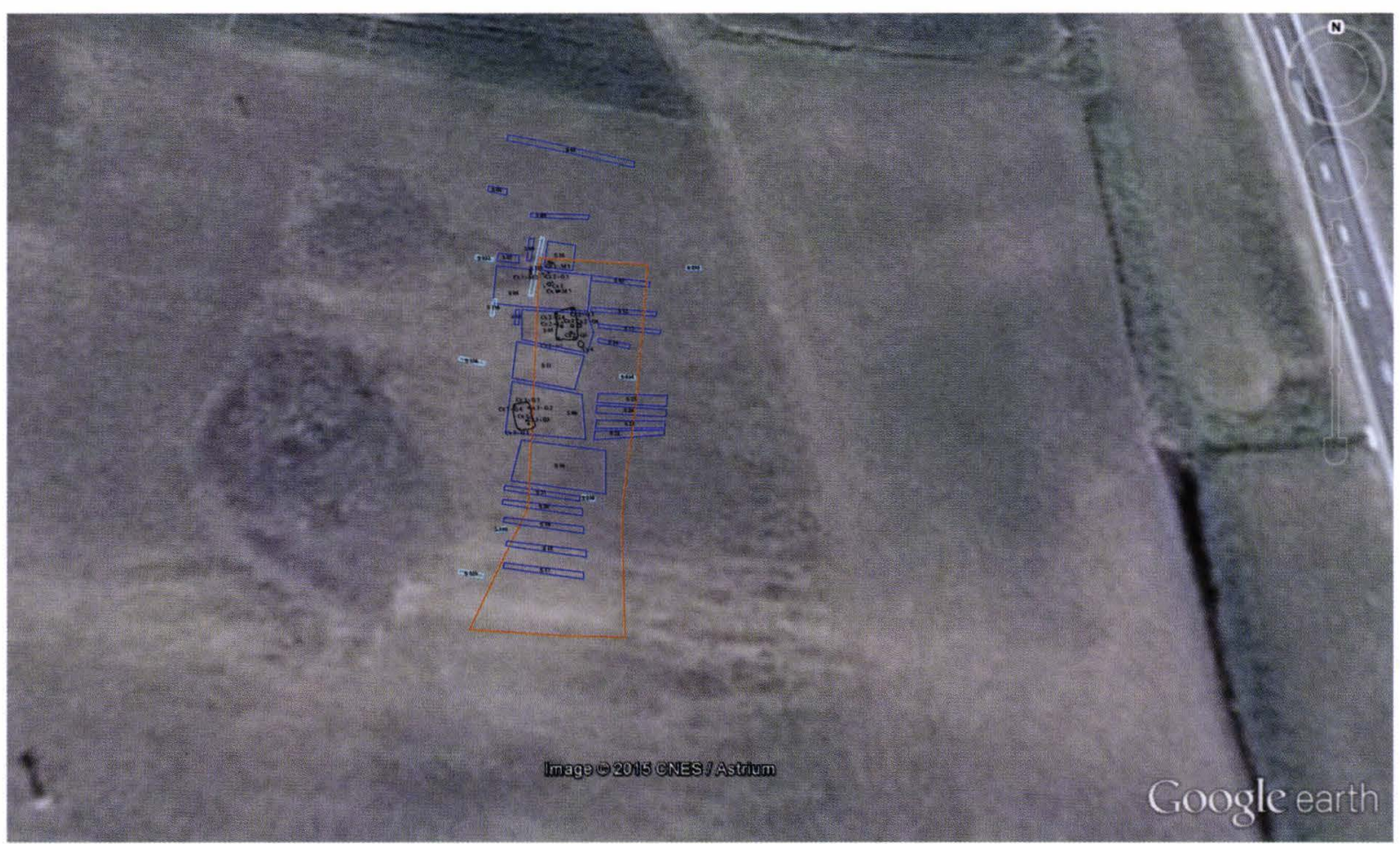

1.

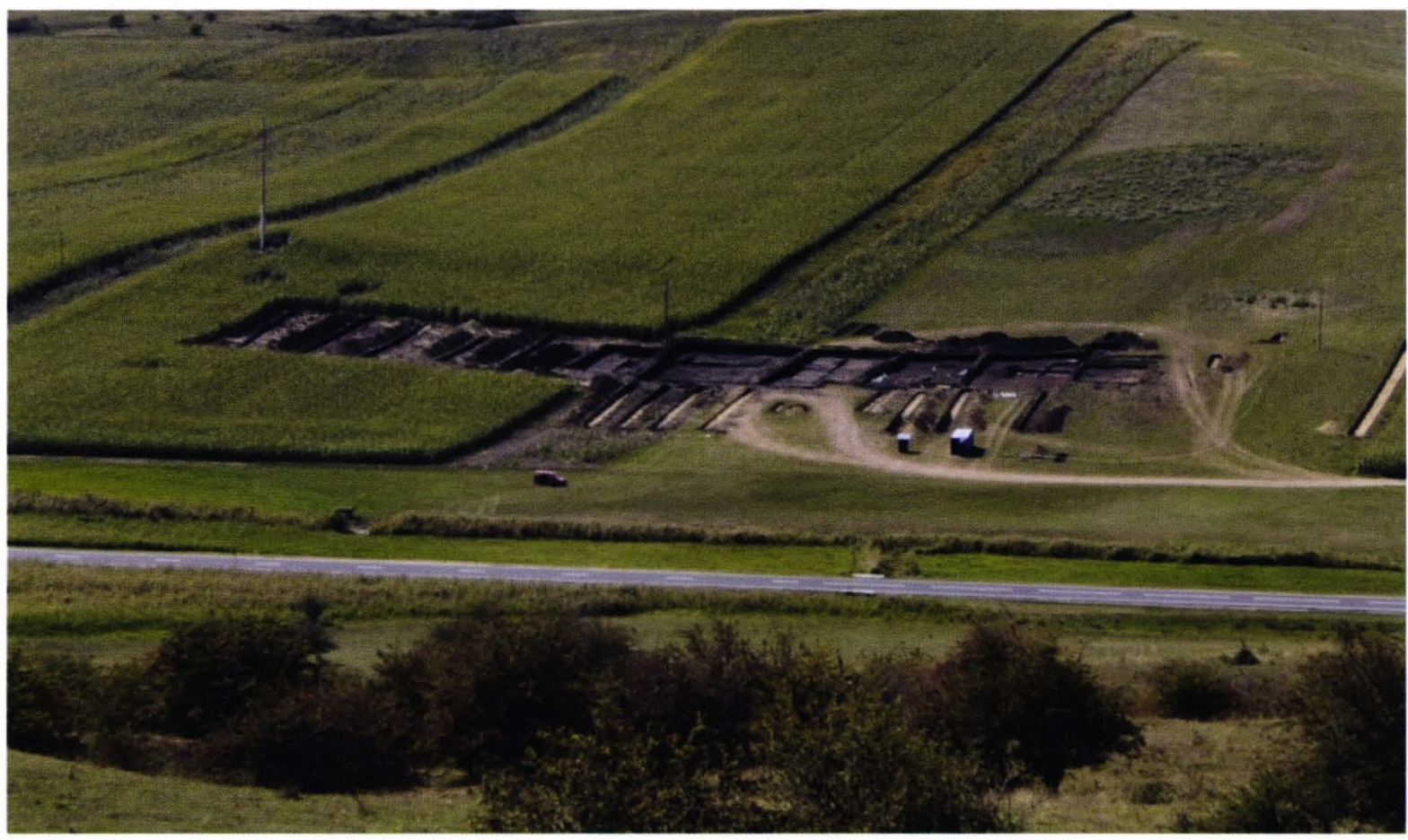

2.

Situl arheologic Stejeriş I: 1. Plan general al săpăturilor arheologic (suprapus pe o imagine Google Maps); 2. Vedere panoramică dinspre est 


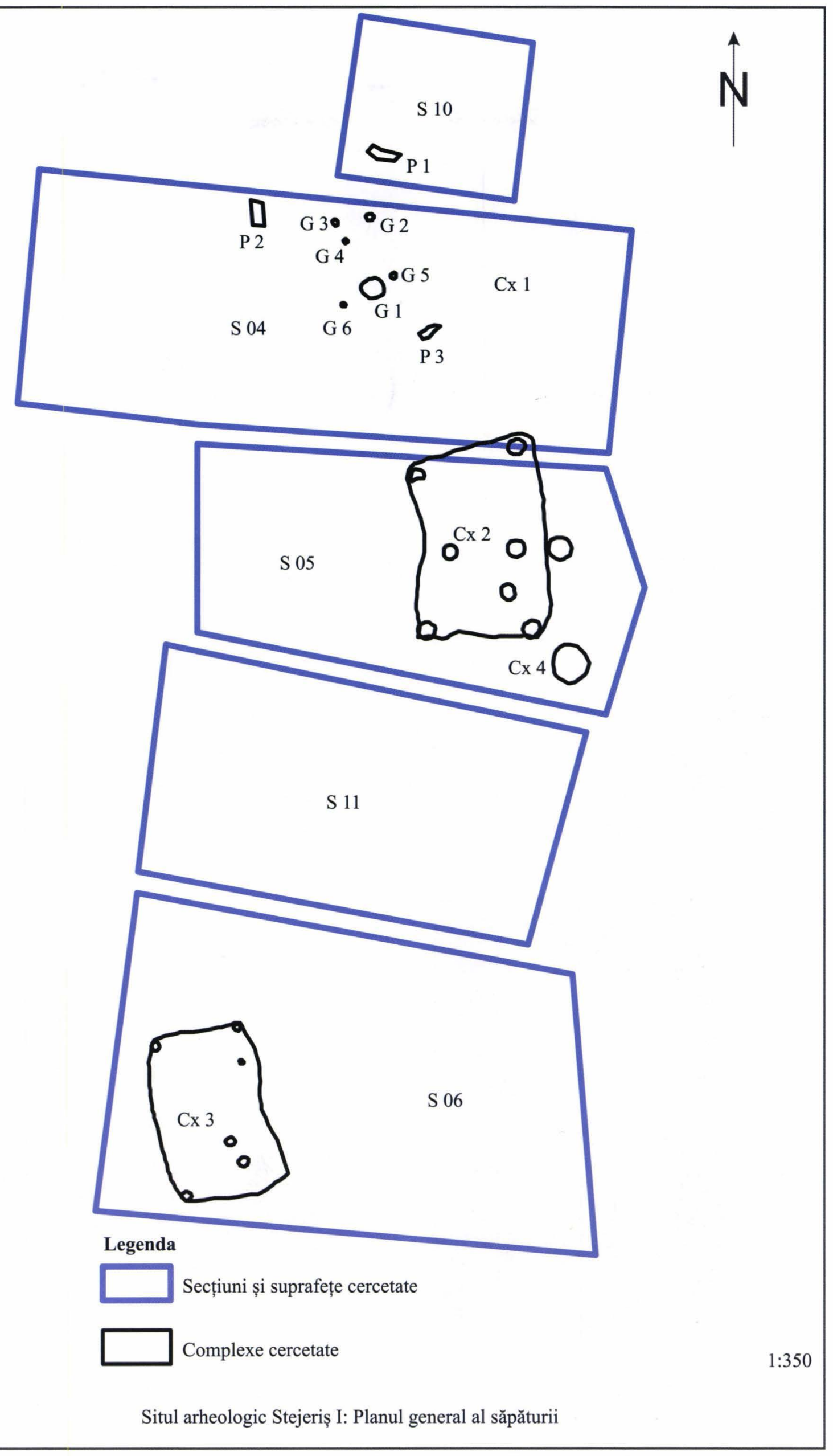

PI. III 


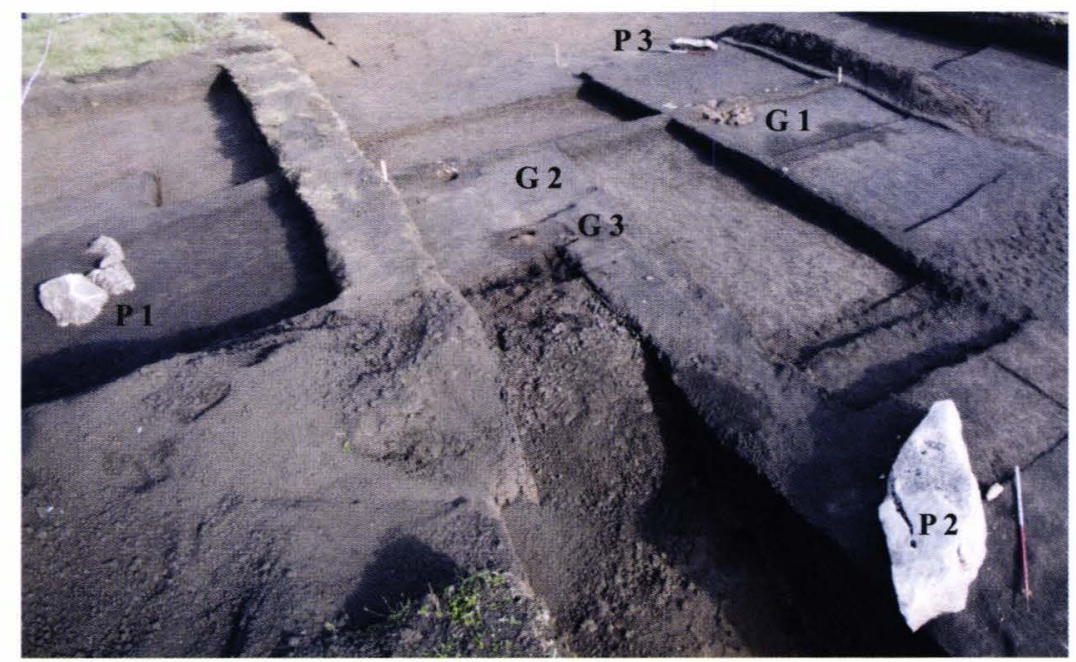

1.

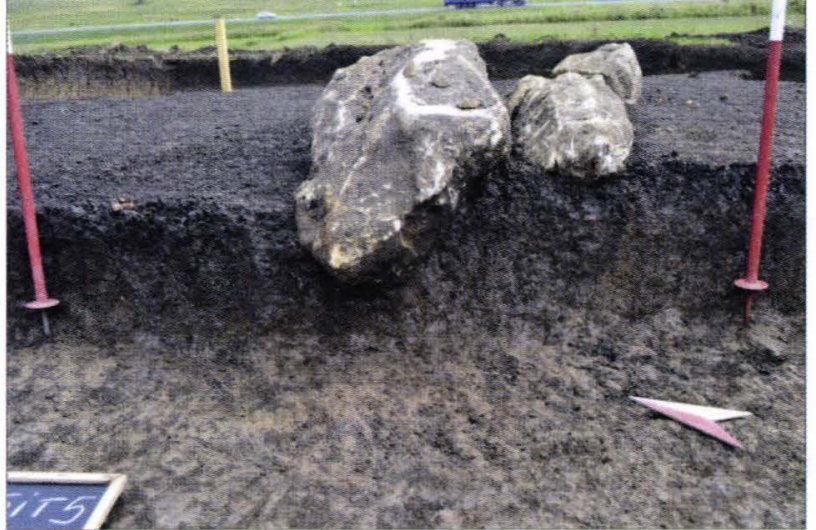

2.

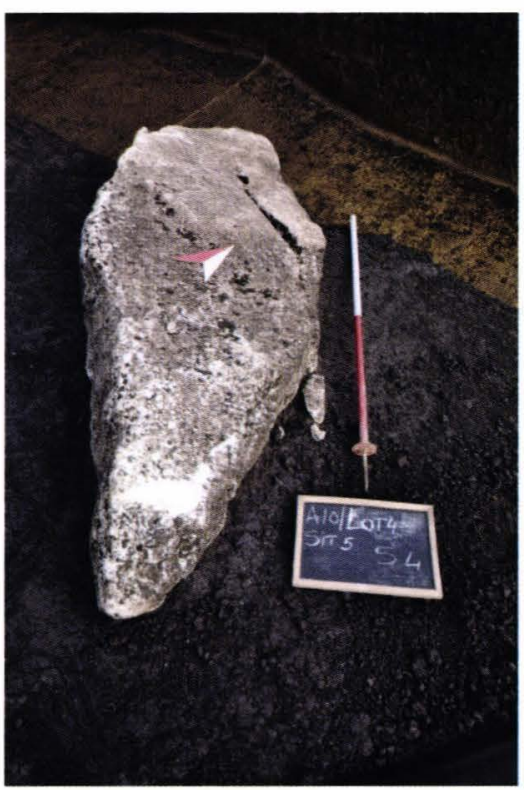

4.

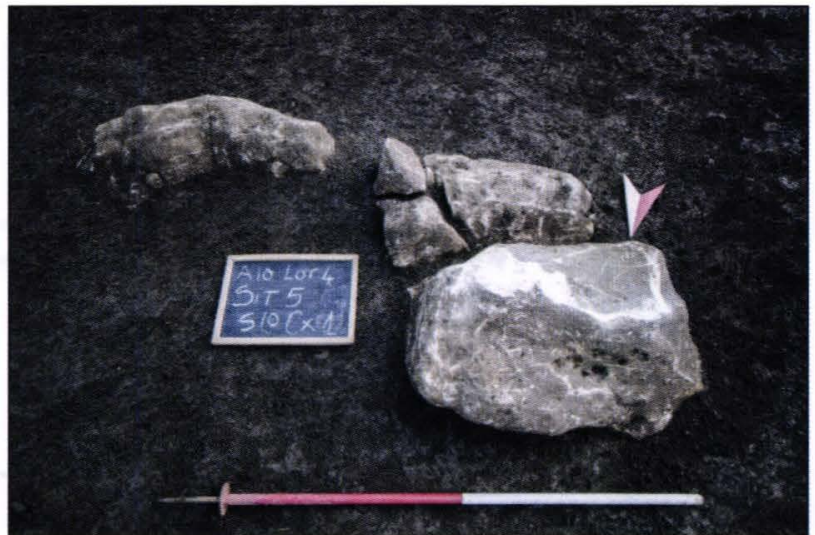

3.

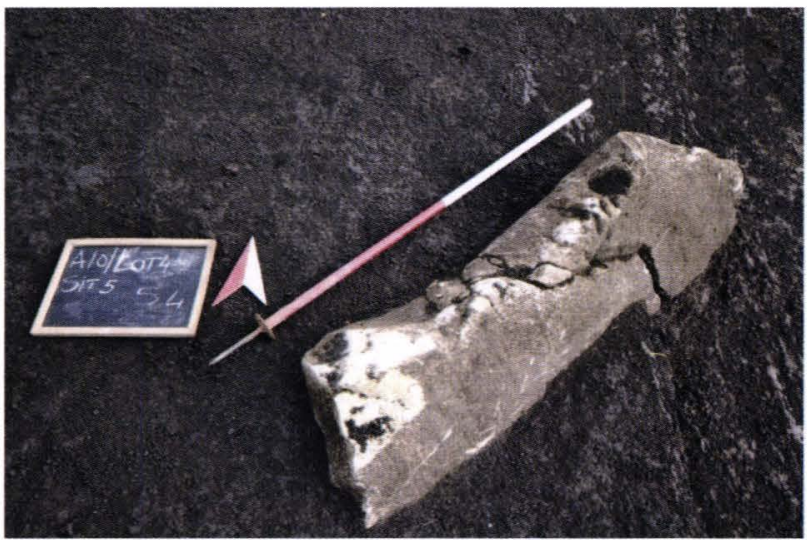

5.

Complexul 1: 1. Imagine de ansamblu dinspre SE; 2. Detaliu (P1) și groapa de implantare (G7) din S. 010; 3. Detaliu (P1) din S. 010; 4. Detaliu (P2) din S. 004; 5. Detaliu (P3) din S.004 


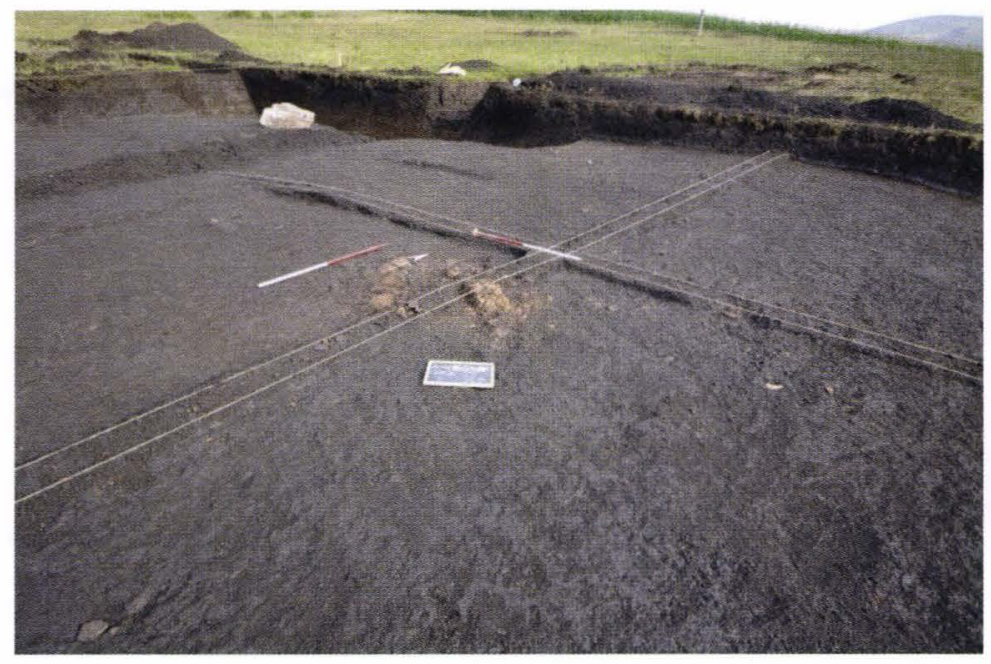

1.

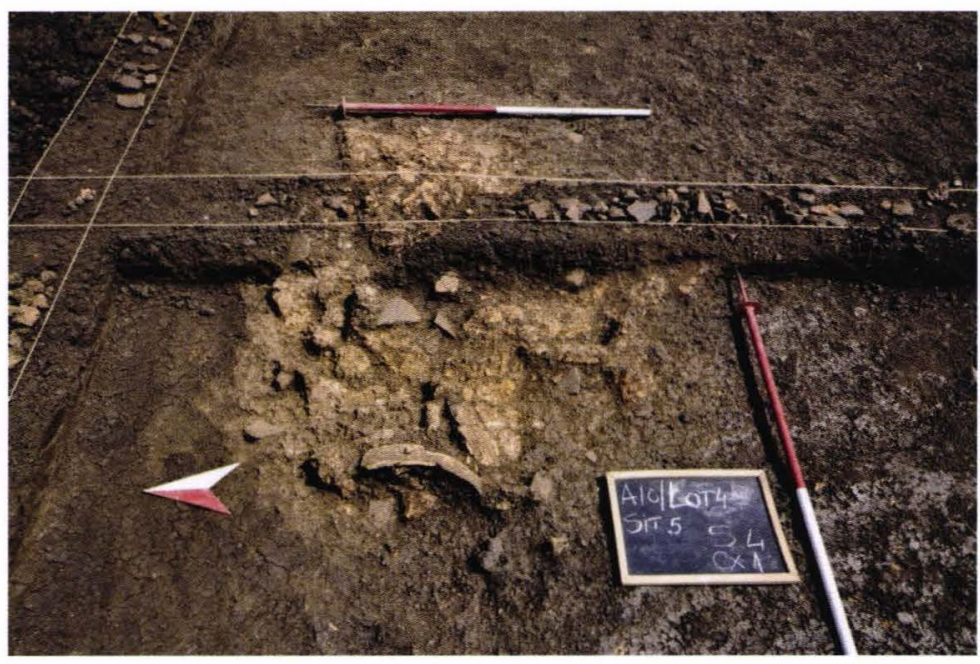

2.

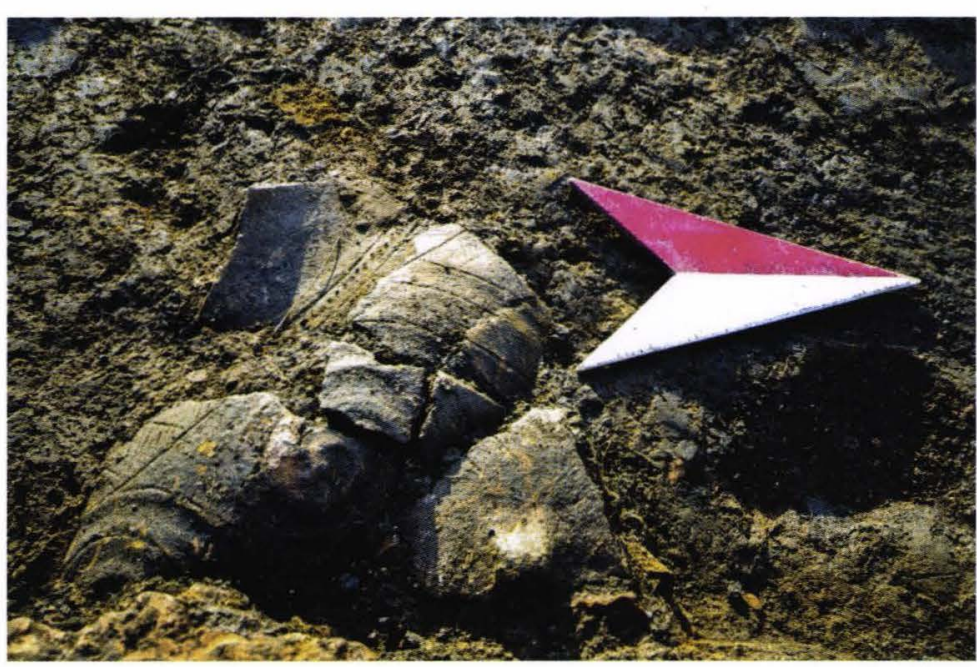

3.

Complexul 1: 1. Vedere de ansamblu dinspre SE (la momentul descoperirii); 2. Vedere dinspre sud (detaliu); 3. Fragmente ceramice in situ (detaliu) 


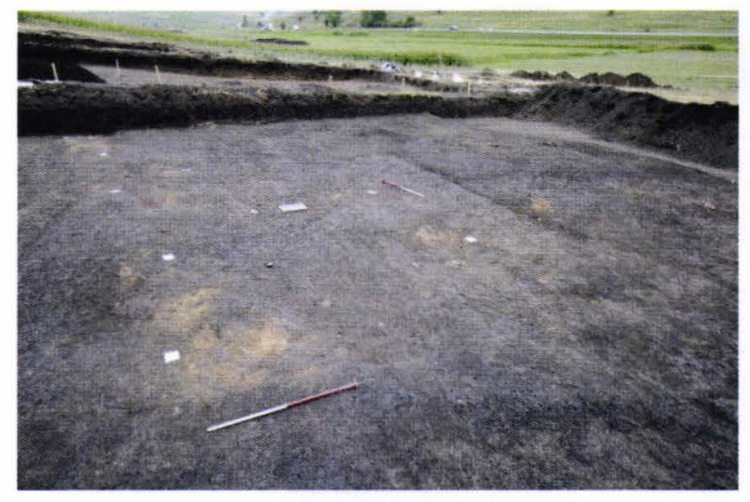

1.

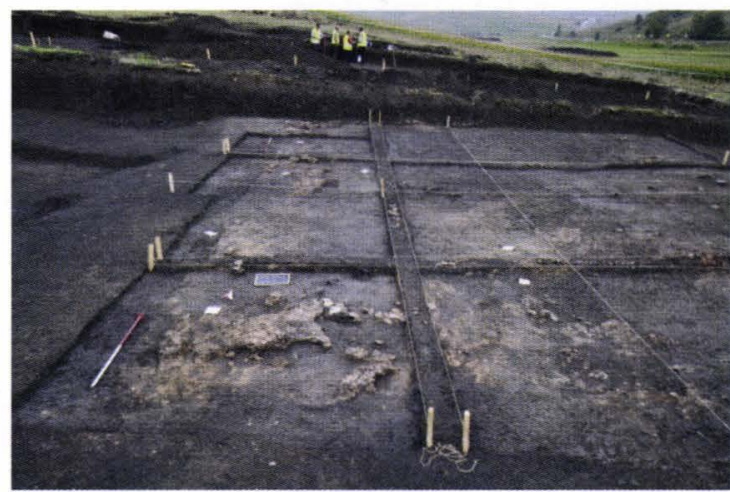

3.

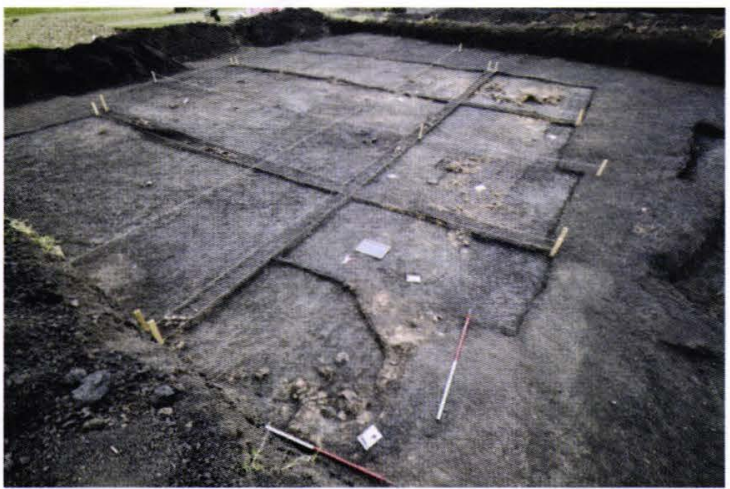

2.

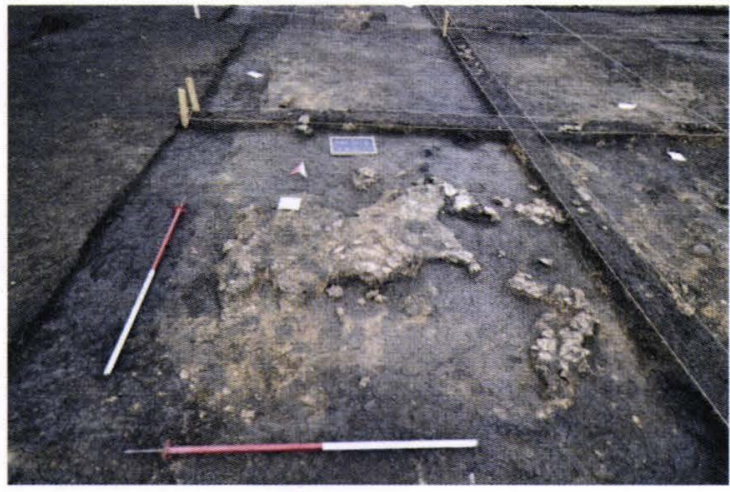

4.

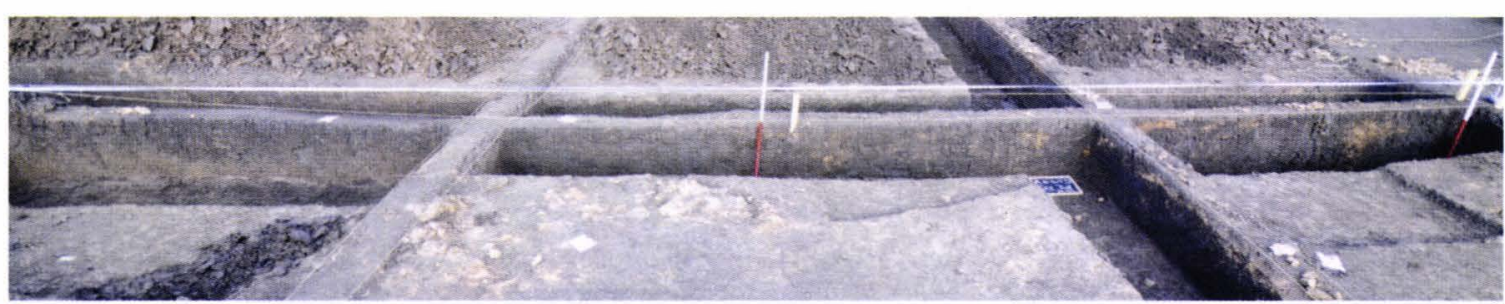

5.

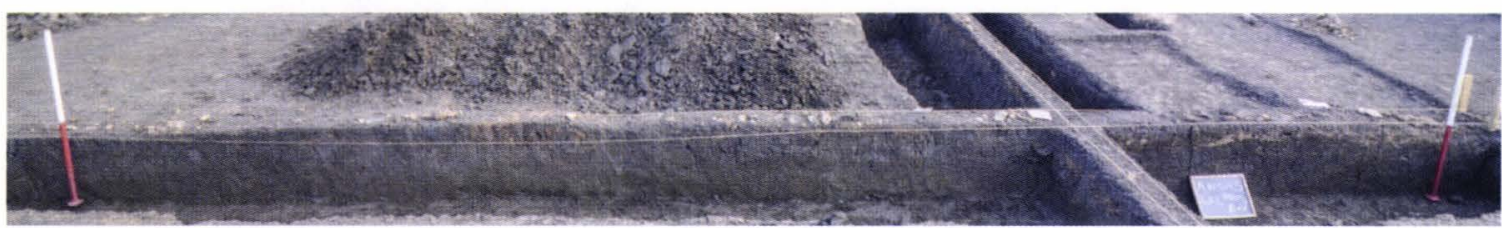

6.

Complexul 2 (locuință de suprafaţă): 1. Imagine de ansamblu dinspre NV; 2. Imagine de ansamblu dinspre SV, la conturare; 3. Imagine de ansamblu dinspre sud; 4. Imagine dinspre sud (detaliu zona de SV); 5. Profil longitudinal; 6. Profil transversal 


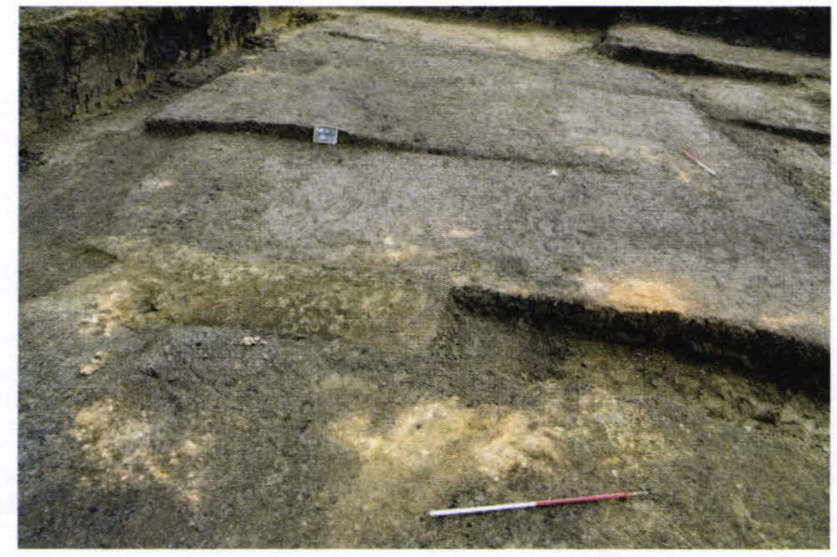

1.

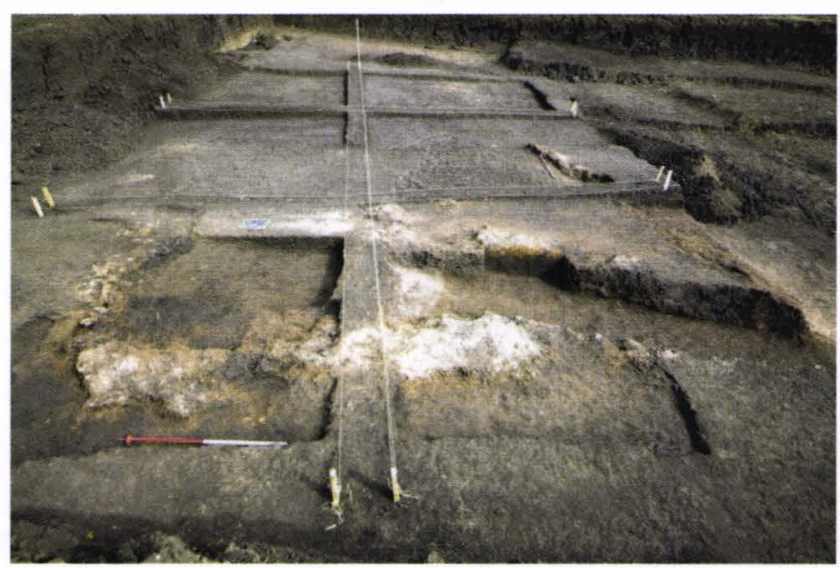

2.

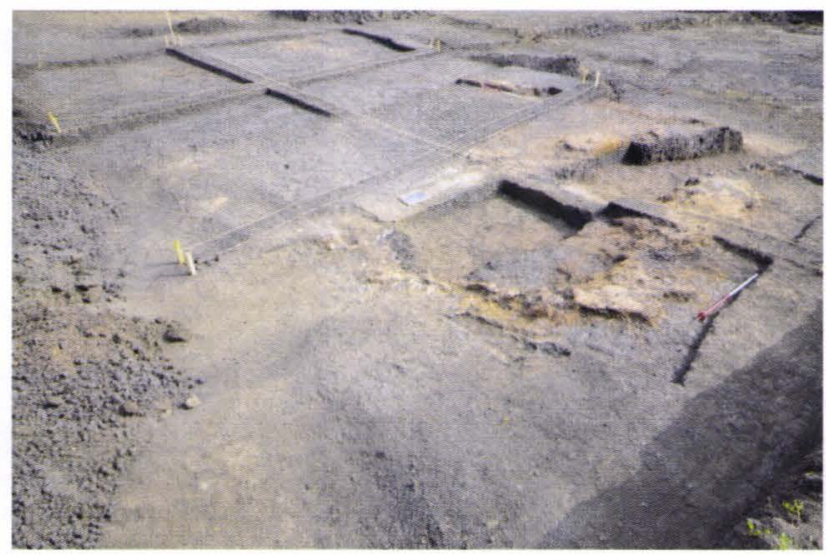

3.

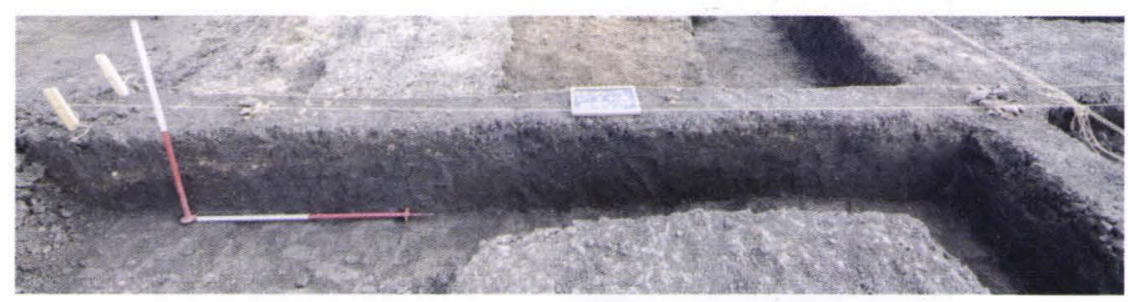

4.

Complexul 3 (locuinţă de suprafaţă): 1. Imagine de ansamblu dinspre sud (la conturare); 2. Imagine de ansamblu dinspre sud; 3. Imagine de ansamblu dinspre SE; 4. Profil transversal 


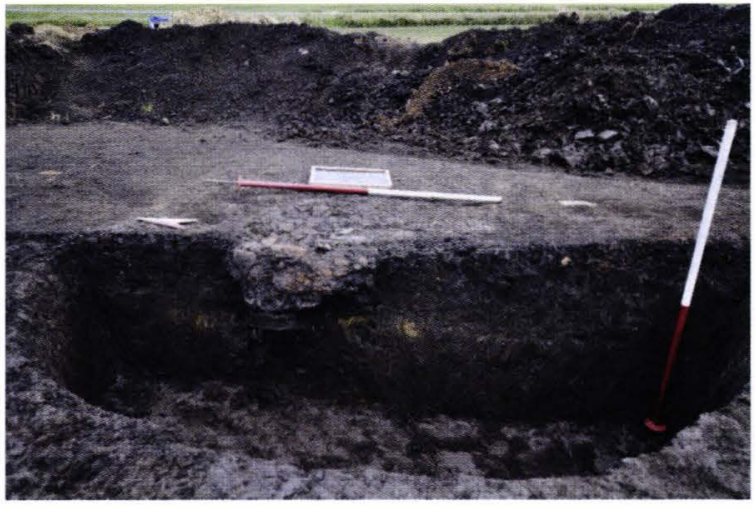

1.

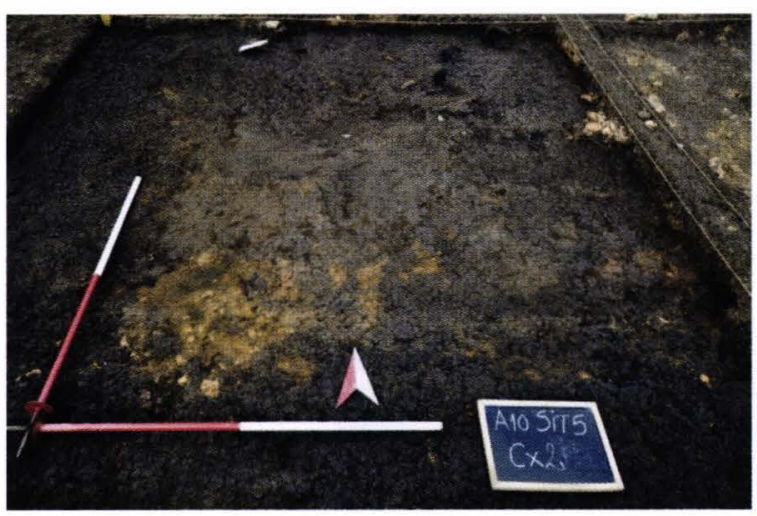

3.

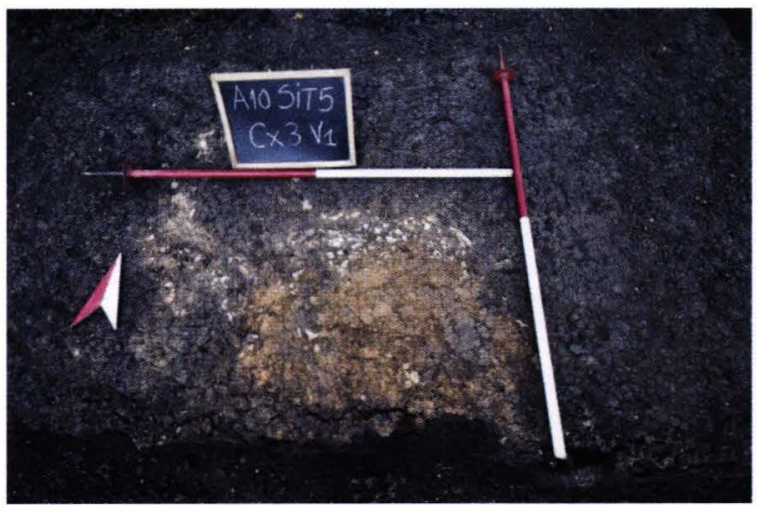

5.

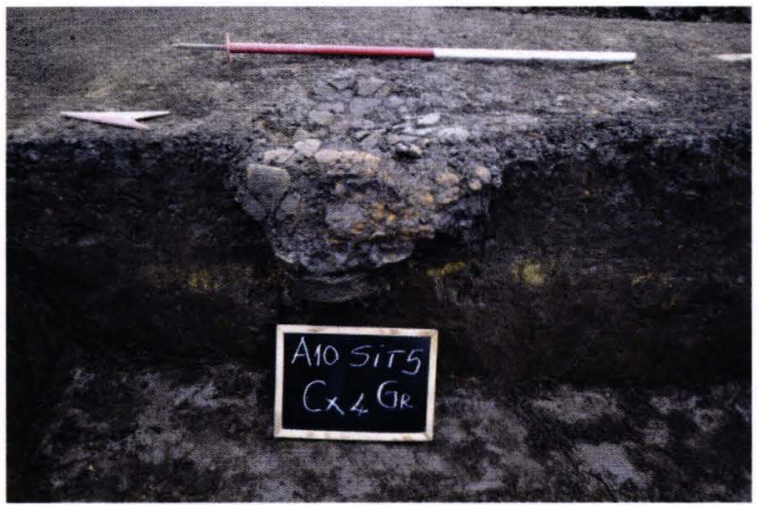

2.

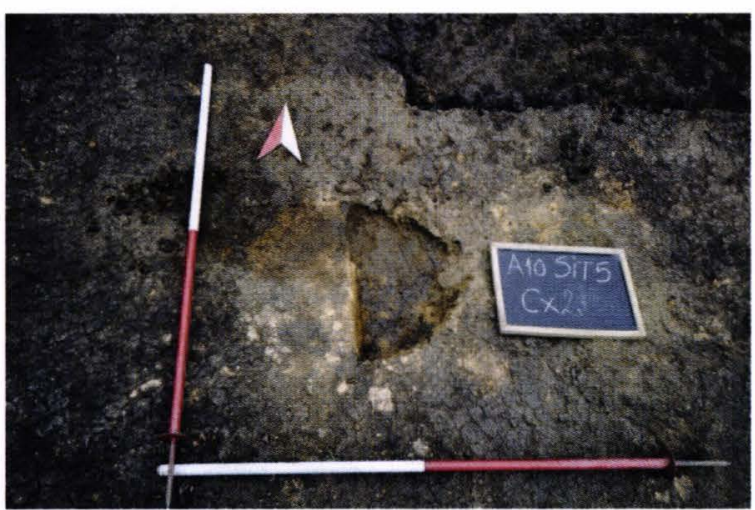

4.

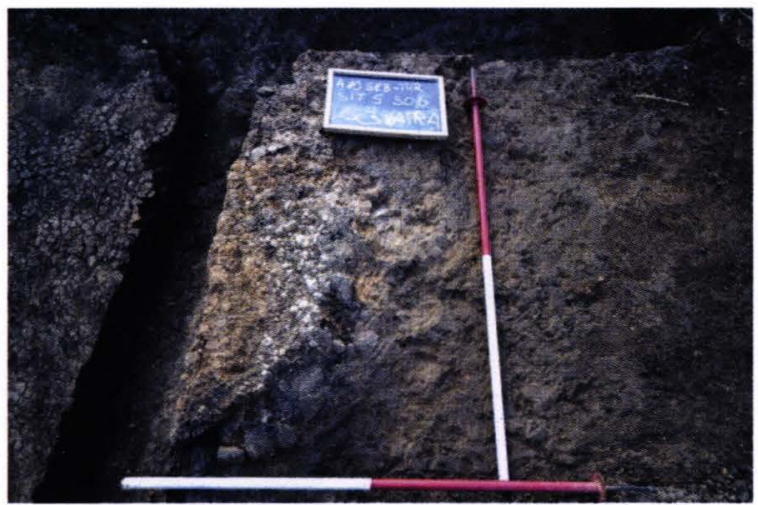

6.

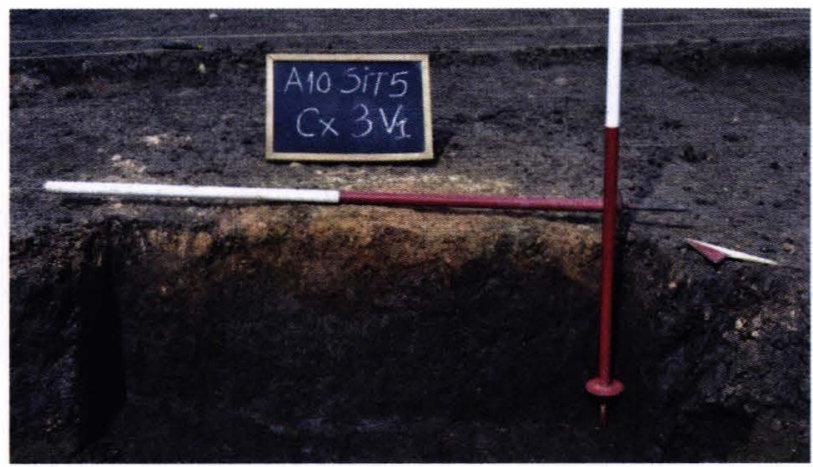

7.

1. Complexul 4, profil; 2. Complexul 4, vas in situ; 3. Cxomplexul 2, groapă de par; 4. Complexul 2, groapă de par; 5. Complexul 3, vatră; 6. Complexul 3, vatră; 7. Complexul 3, vatră (profil) 


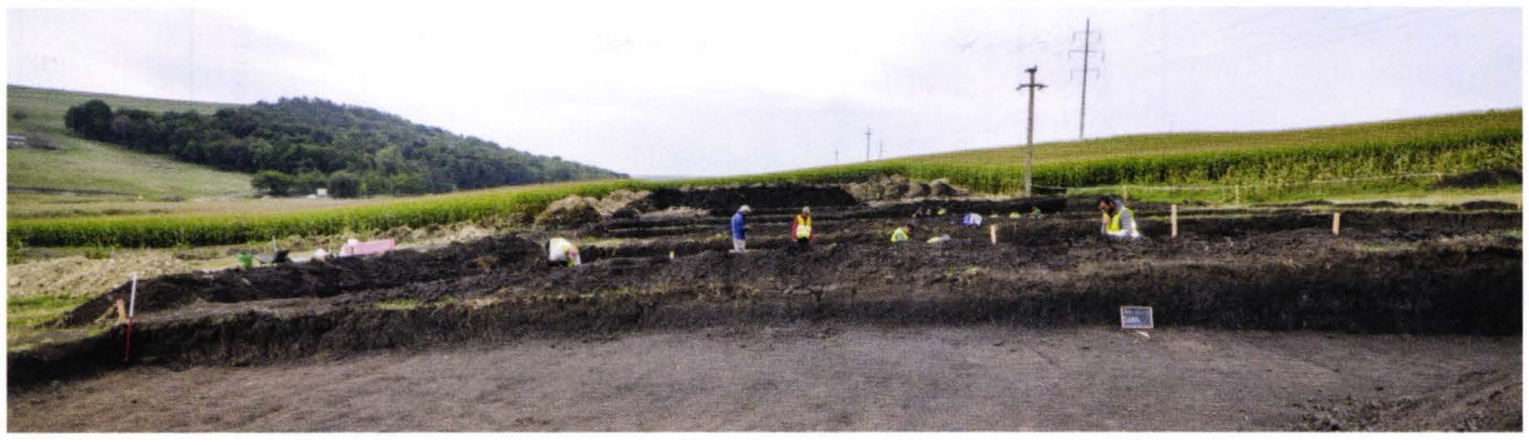

1.

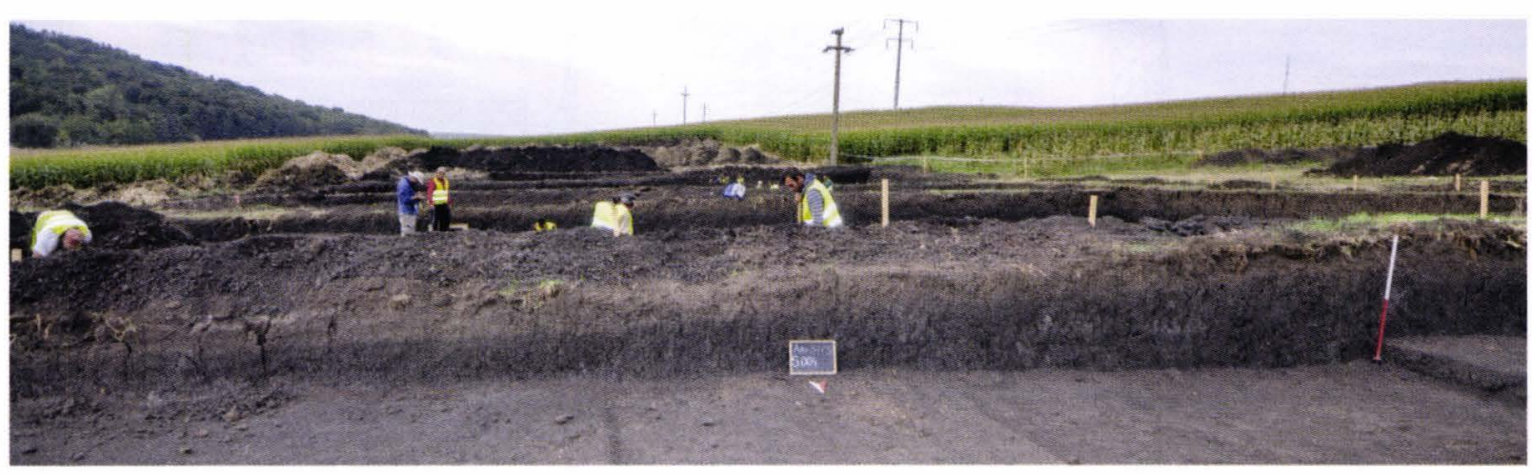

2.

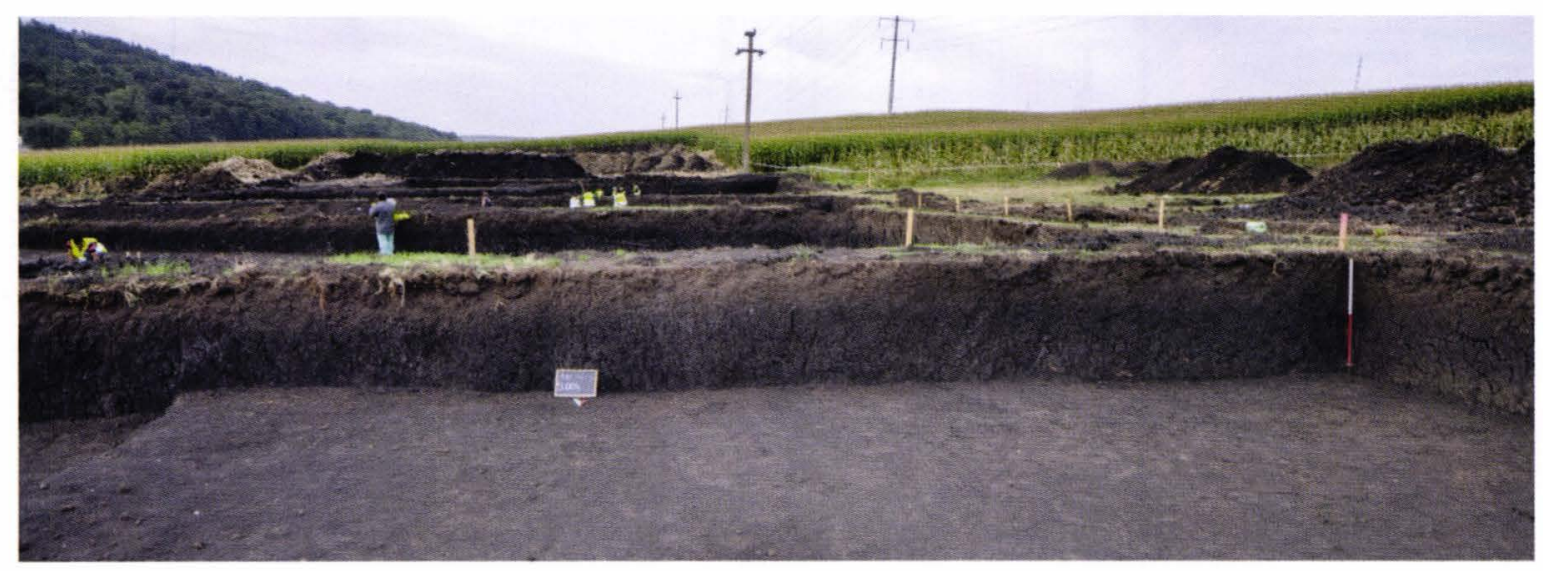

3.

1-3. S. 004, profilul de sud

PI. IX 


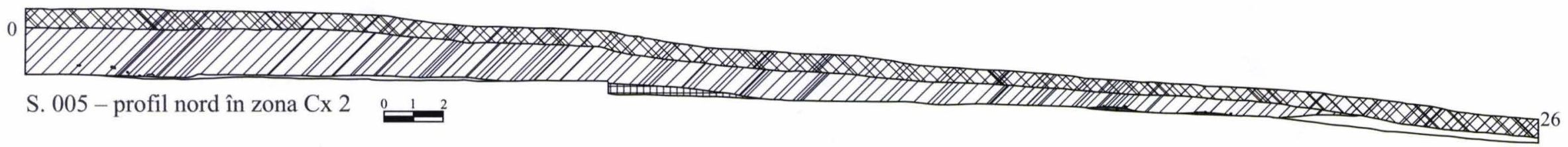

S. 005 - profil nord în zona $\mathrm{Cx} 2$

\section{니}

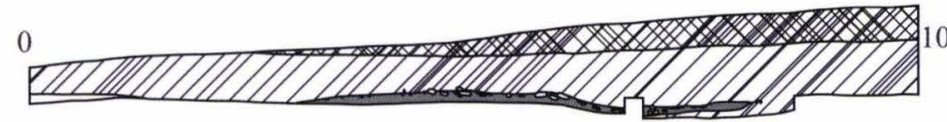

S. 004 - profil sud în zona Cx 2

Legendă

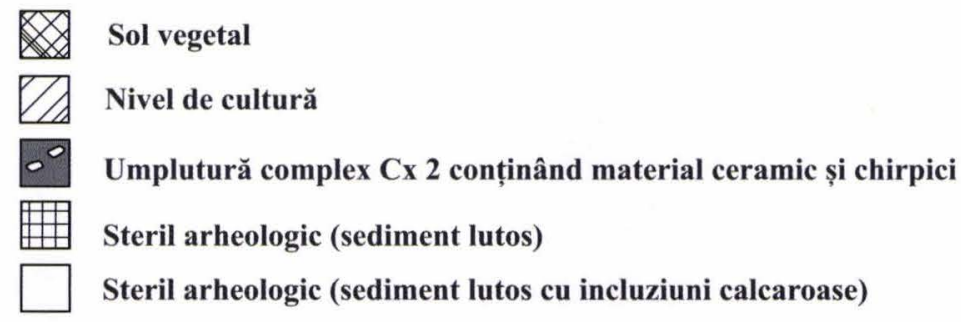

S. 004, profilul de sud al suprafetei de săpătură cu resturi din locuința de suprafață (complexul 2)

S. 005, profilul de nord al suprafeței de săpătură cu resturi din locuința de suprafață (complexul 2) 


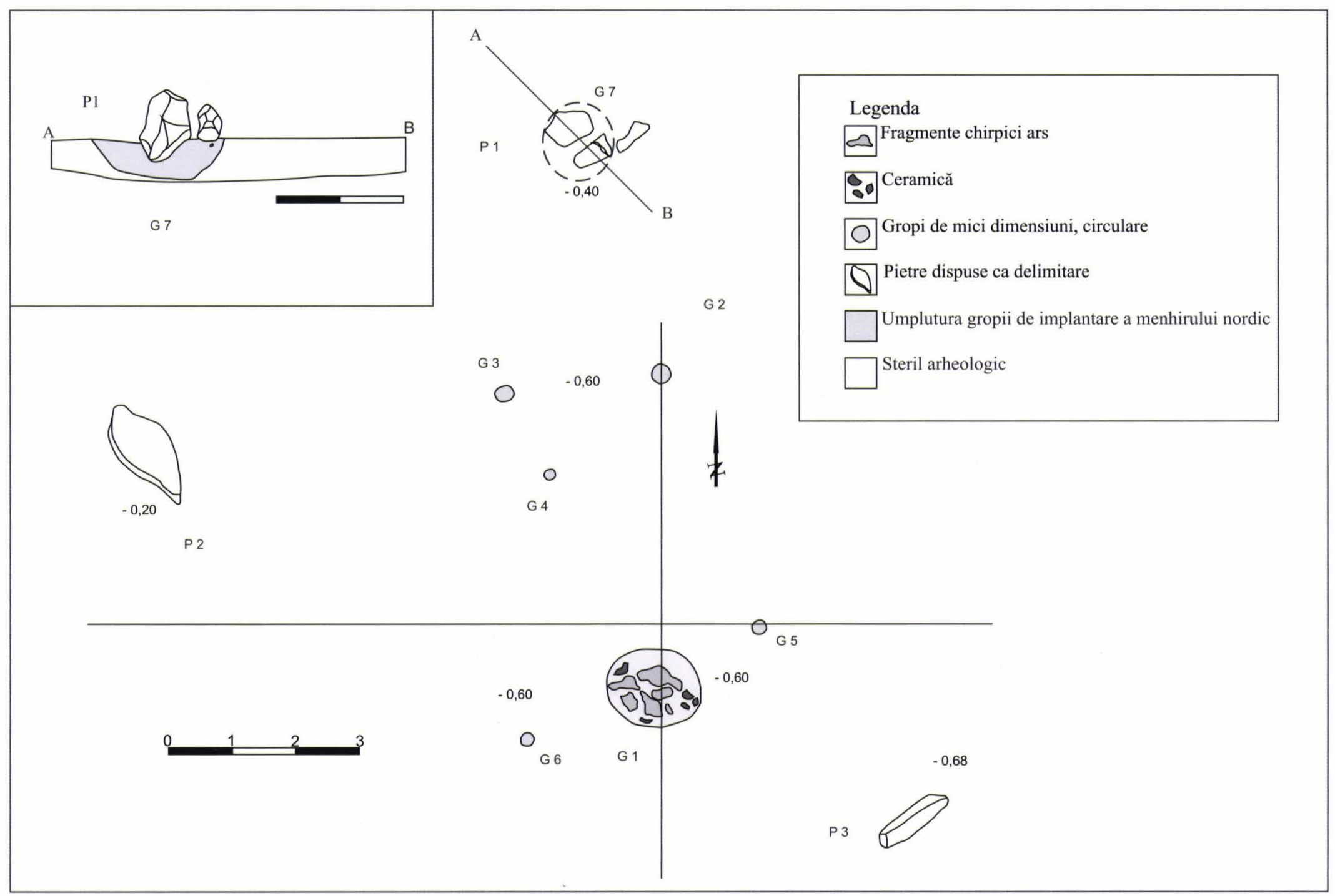

Complexul 1, planul și profilul gropii de implantare al pietrei (P1) 


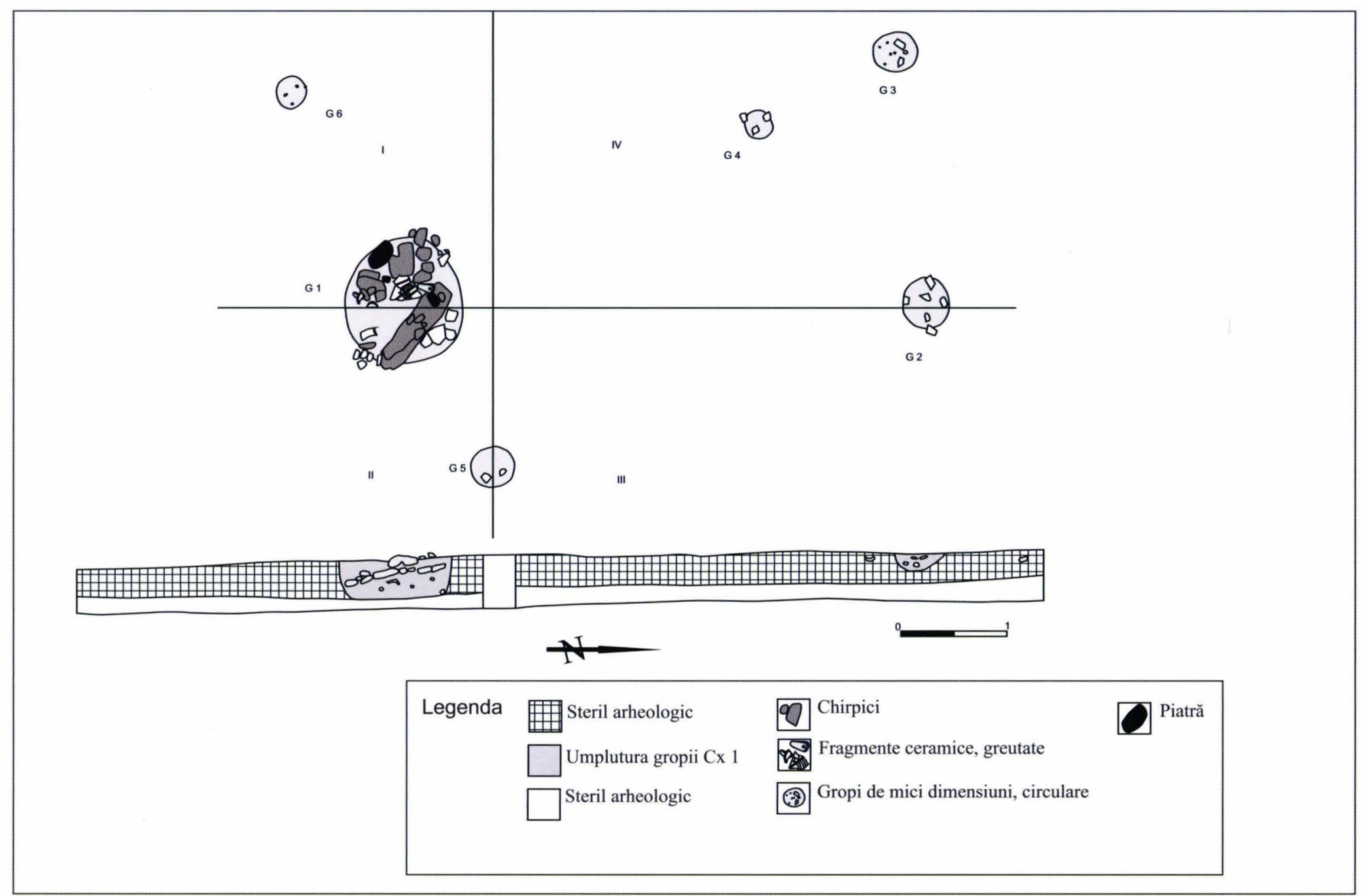

Complexul 1, planul (detaliu) și profilul de vest la secționare 


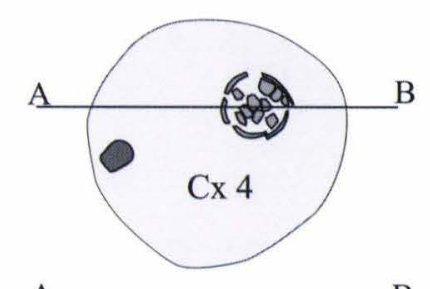

A

A
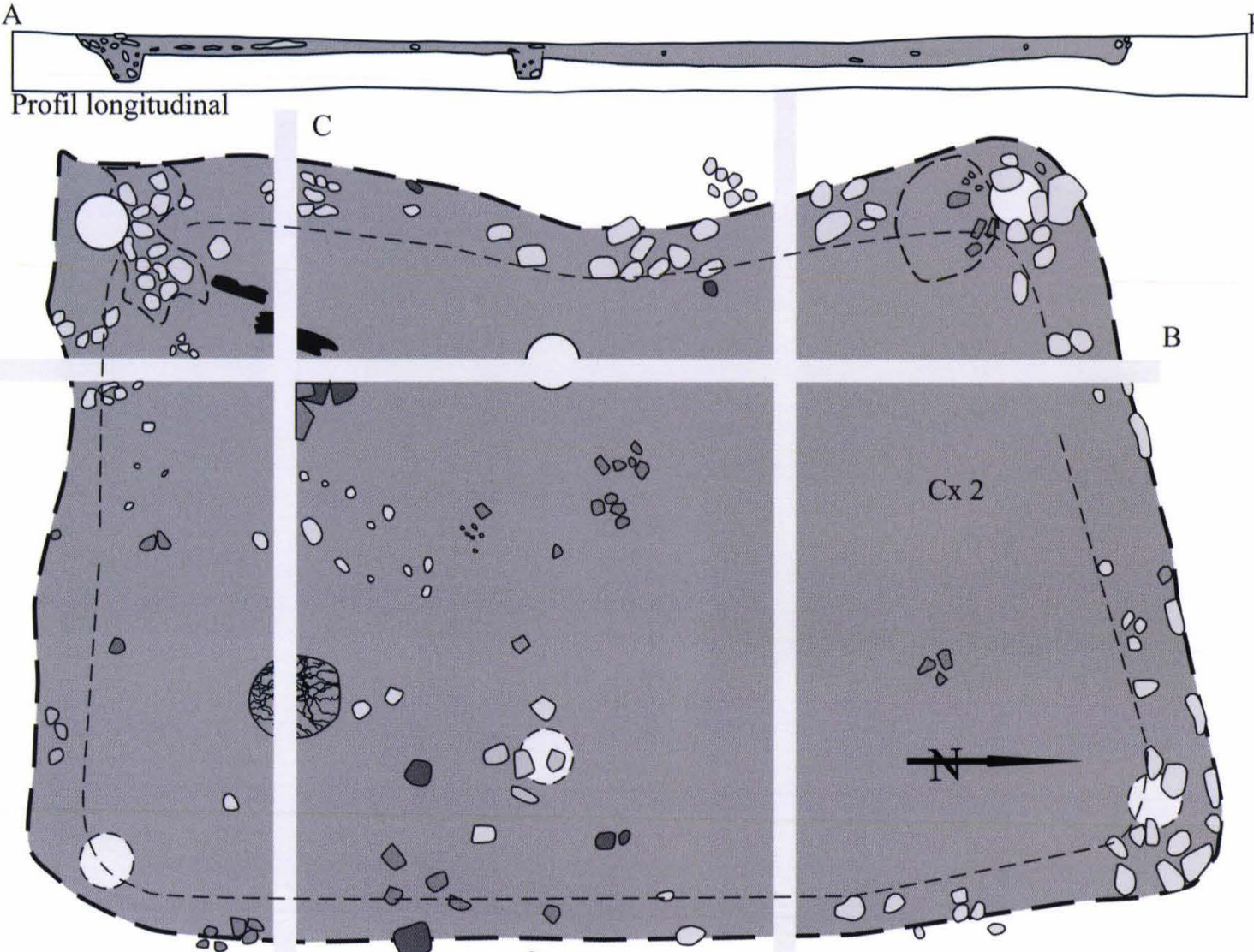

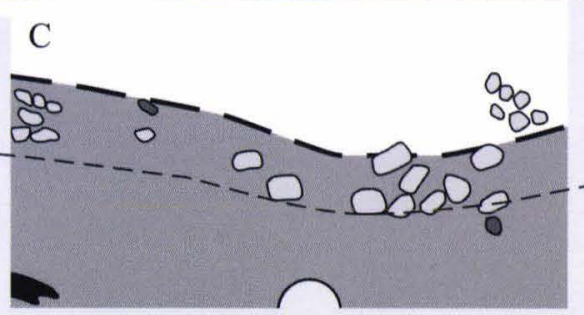

KR
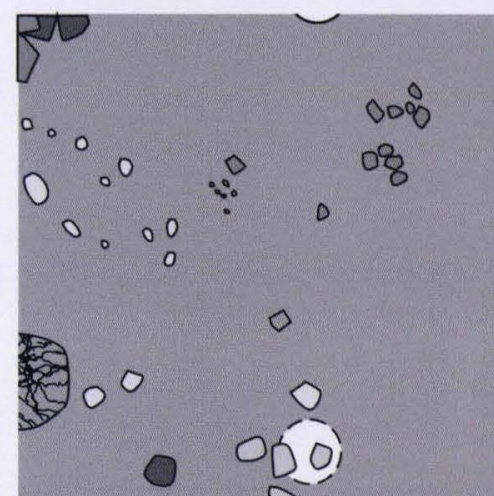

0

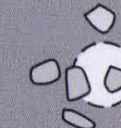

○
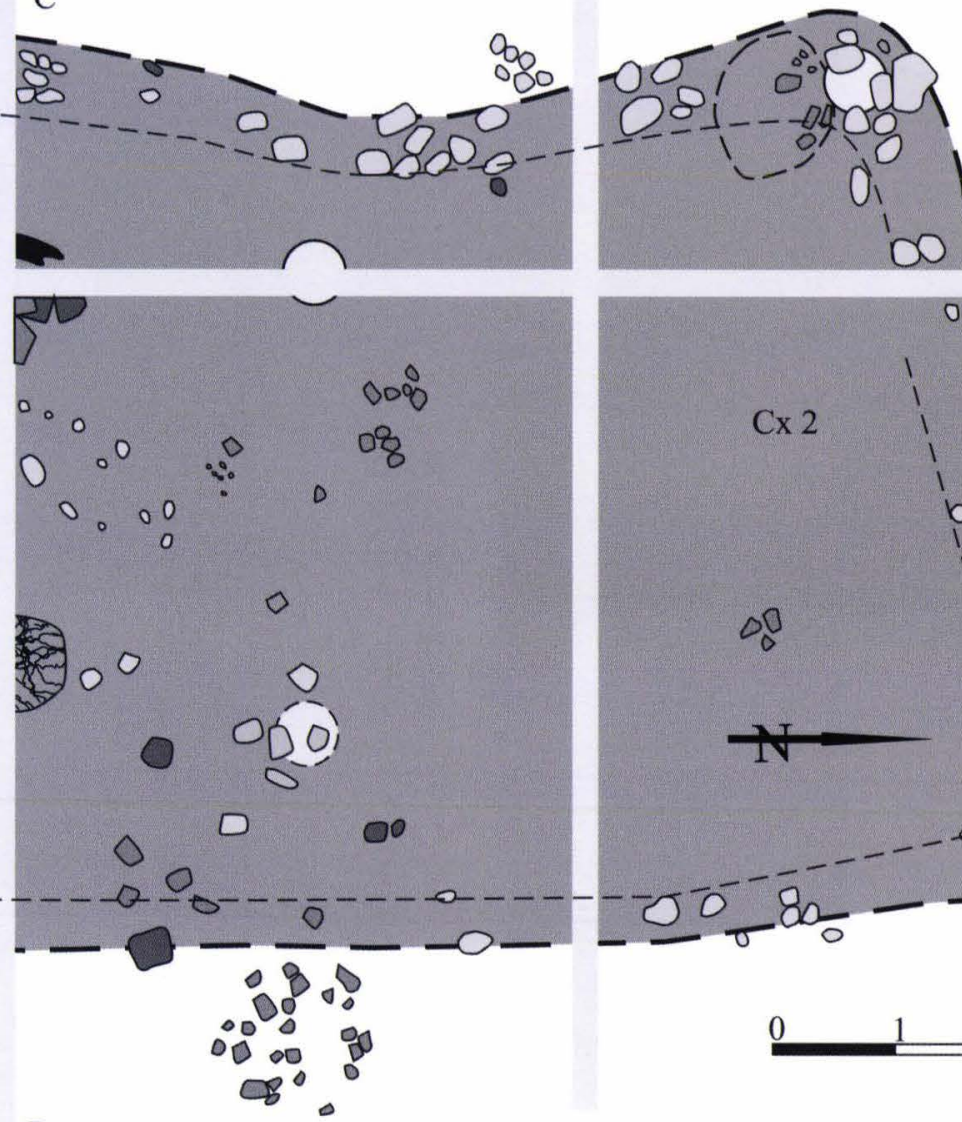

B
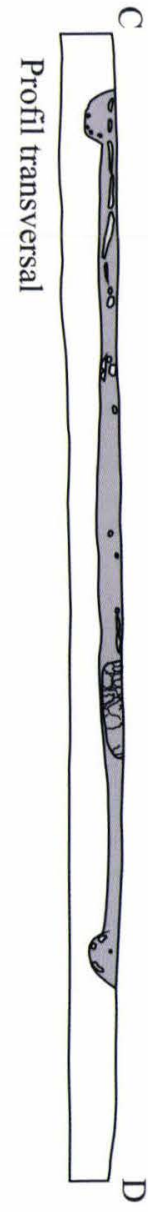

Legend

$\square$ Umputura locuinței Cx 2

Vatră

웅 Fragmente ceramice

80. Chirpici

Vas ceramic

$\square_{\text {Lemn ars }}$

0 Piatră

$\square$ Steril arheologic

Complexul 2, planul și profilul (longitudinal și transversal) locuintei de suprafață;

Complexul 4, planul şi profilul gropii situate la SE de locuință (complexul 2)

\section{PI. XIII}




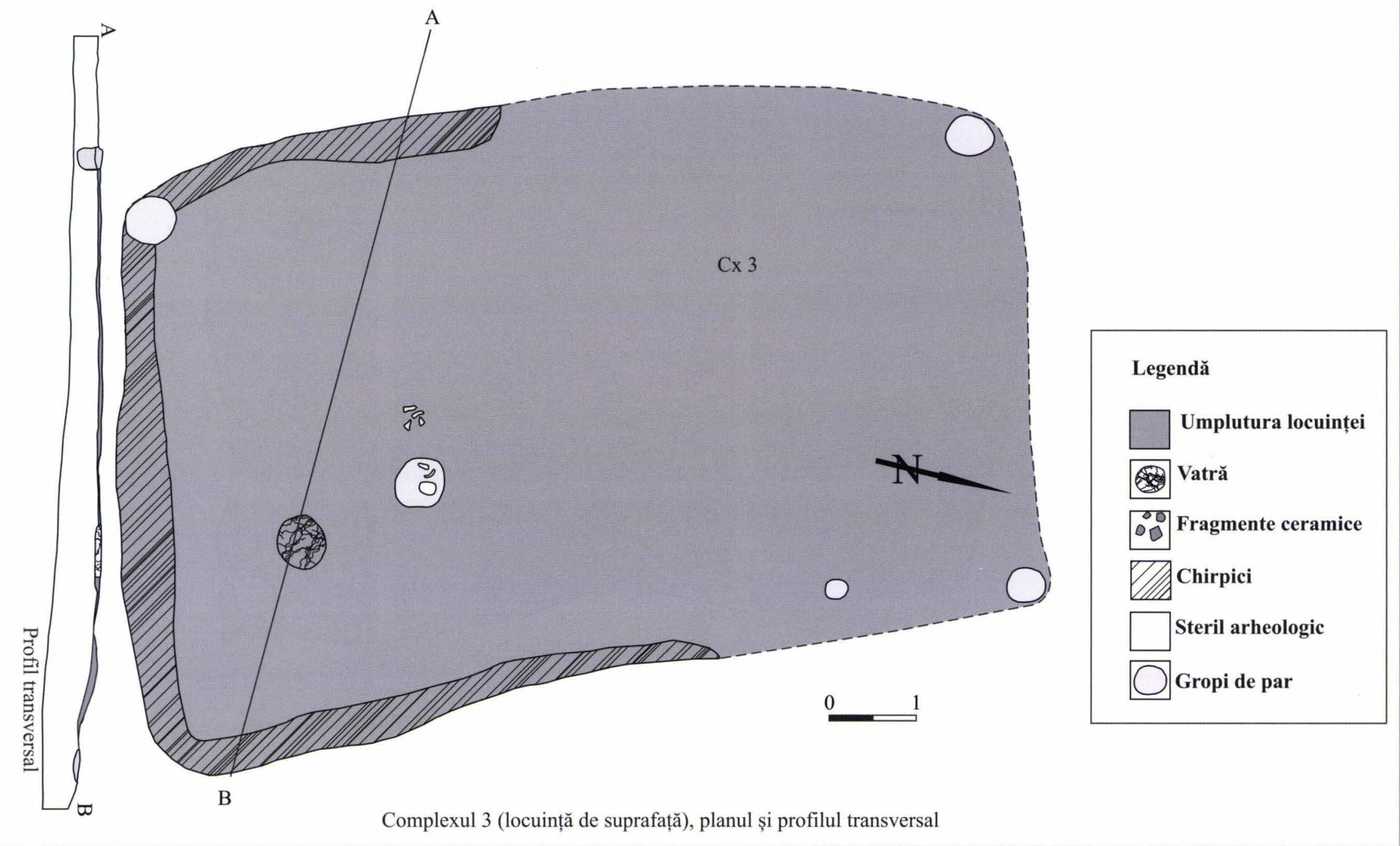




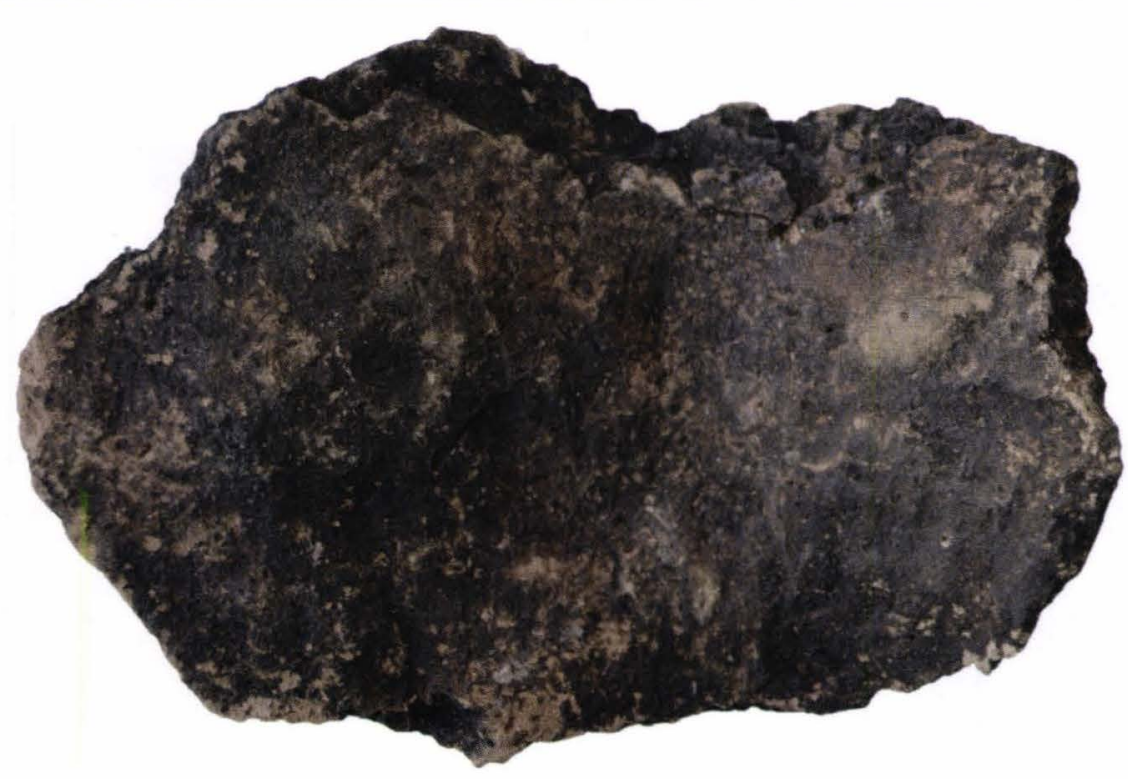

1.

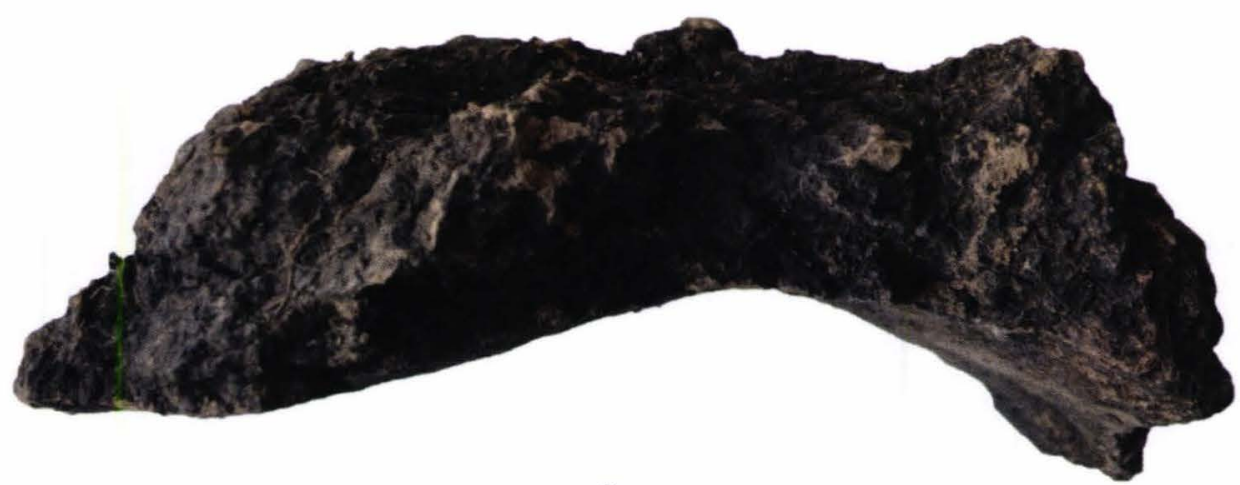

2.

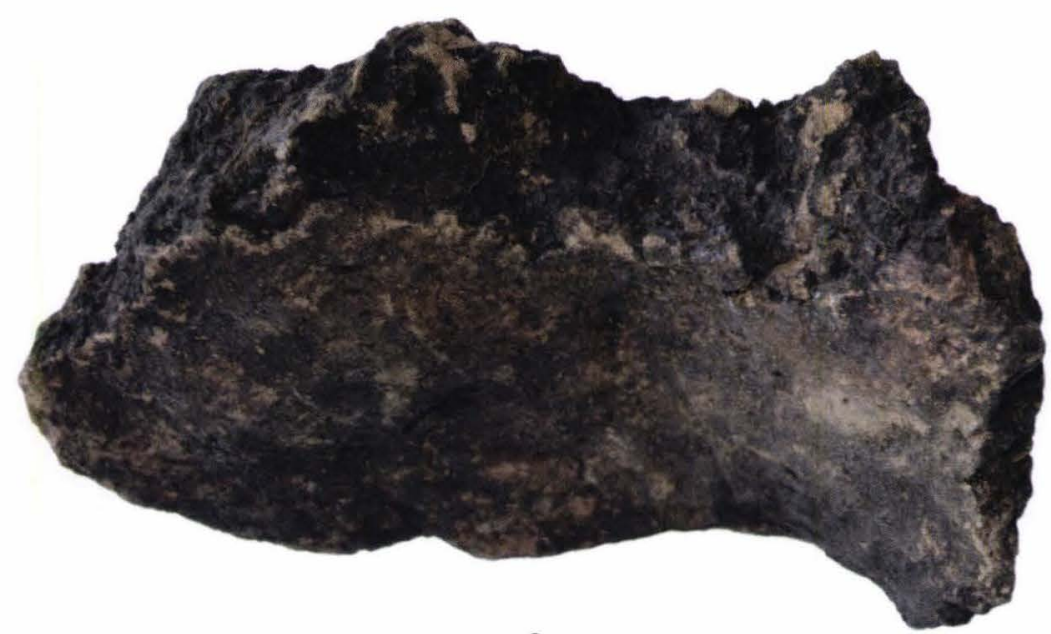

3.

Complexul 1: 1-3. Fragmente de perete 


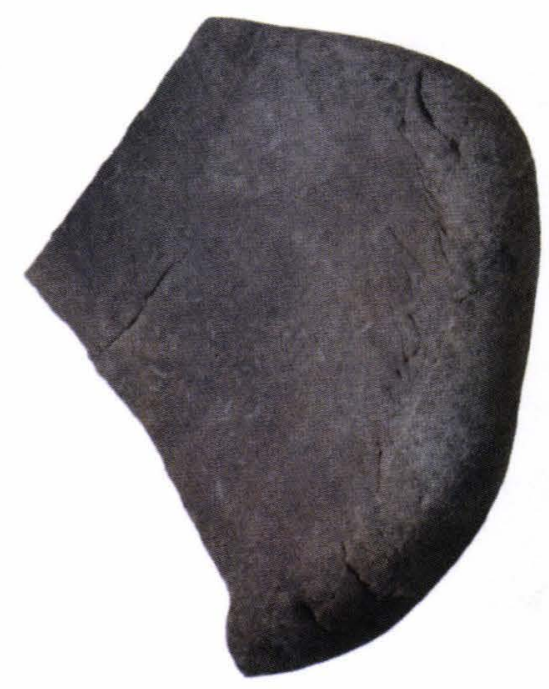

0
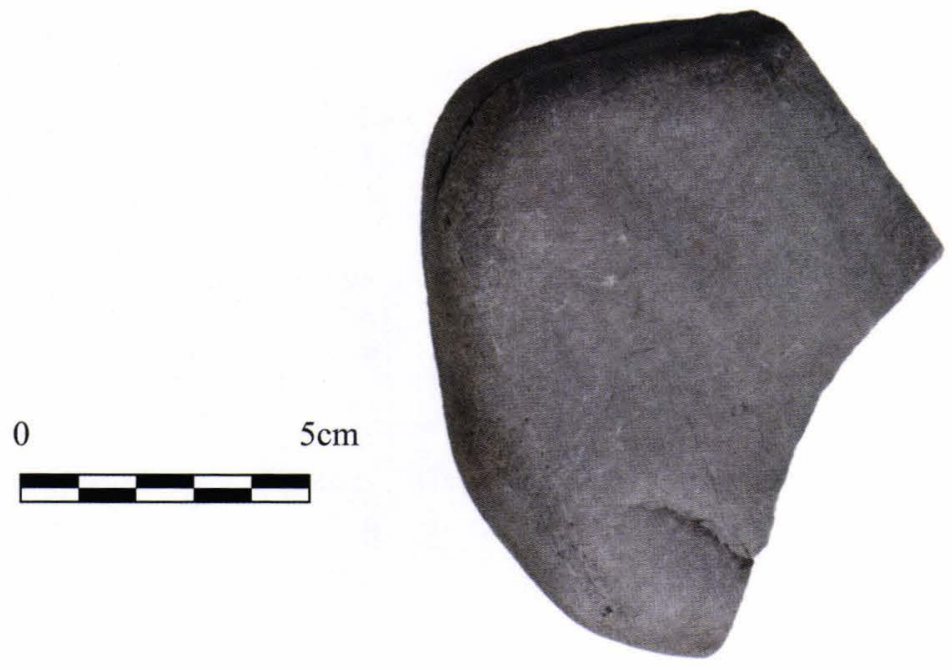

1.

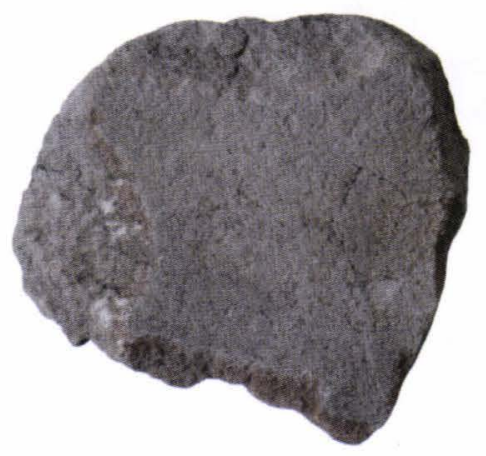

0

$5 \mathrm{~cm}$

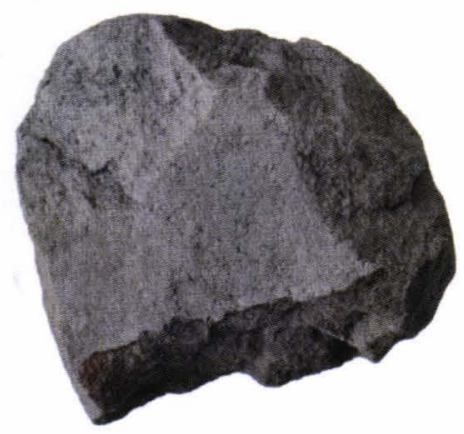

2.
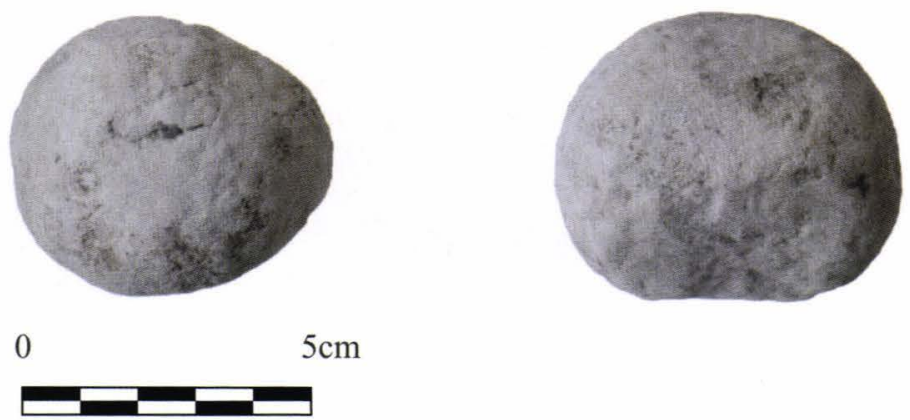

3.

Complexul 2, material litic: 1-2. Fragmente de râșnițe; 3. Lustruitor din piatră 

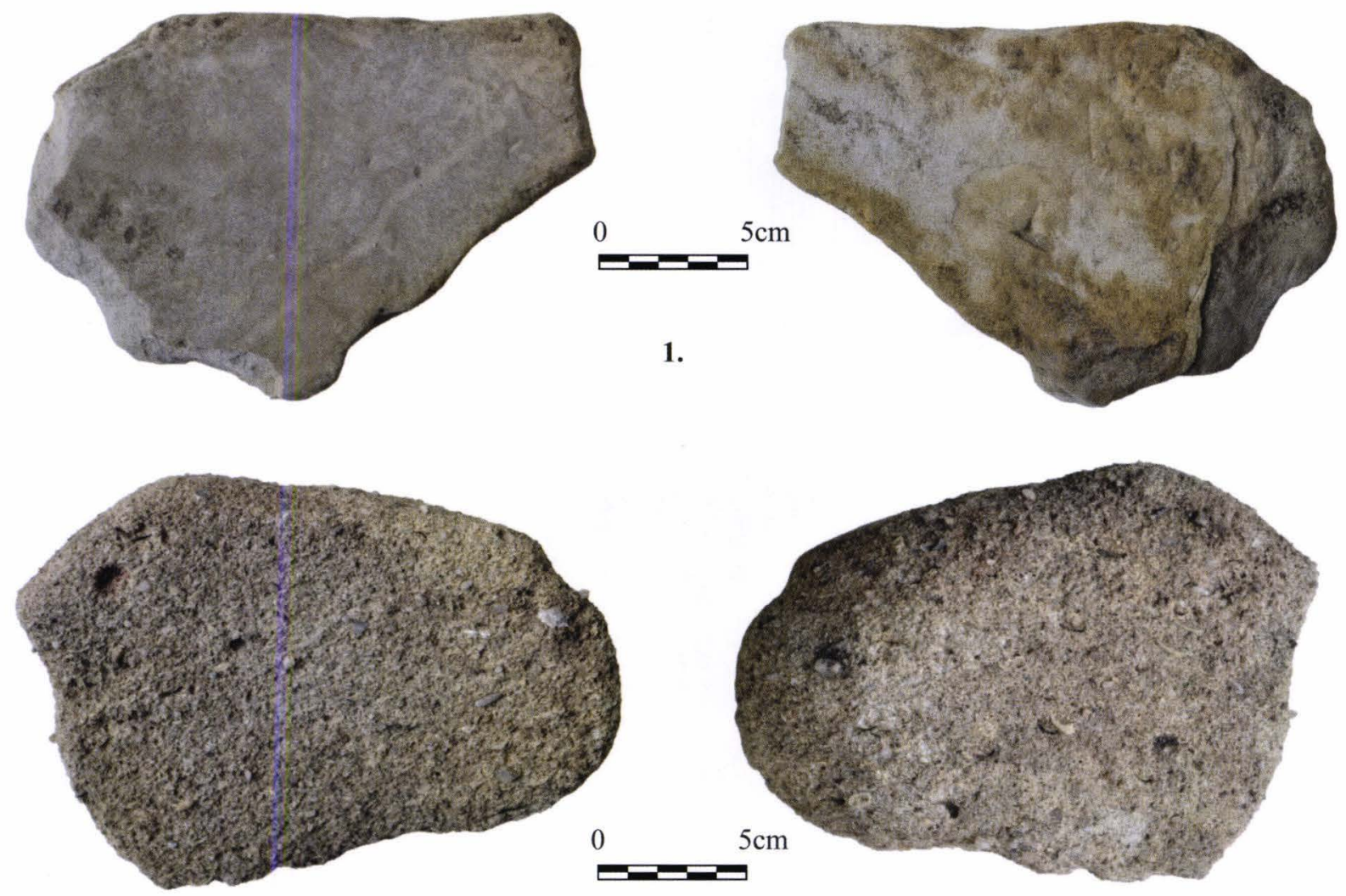

2.
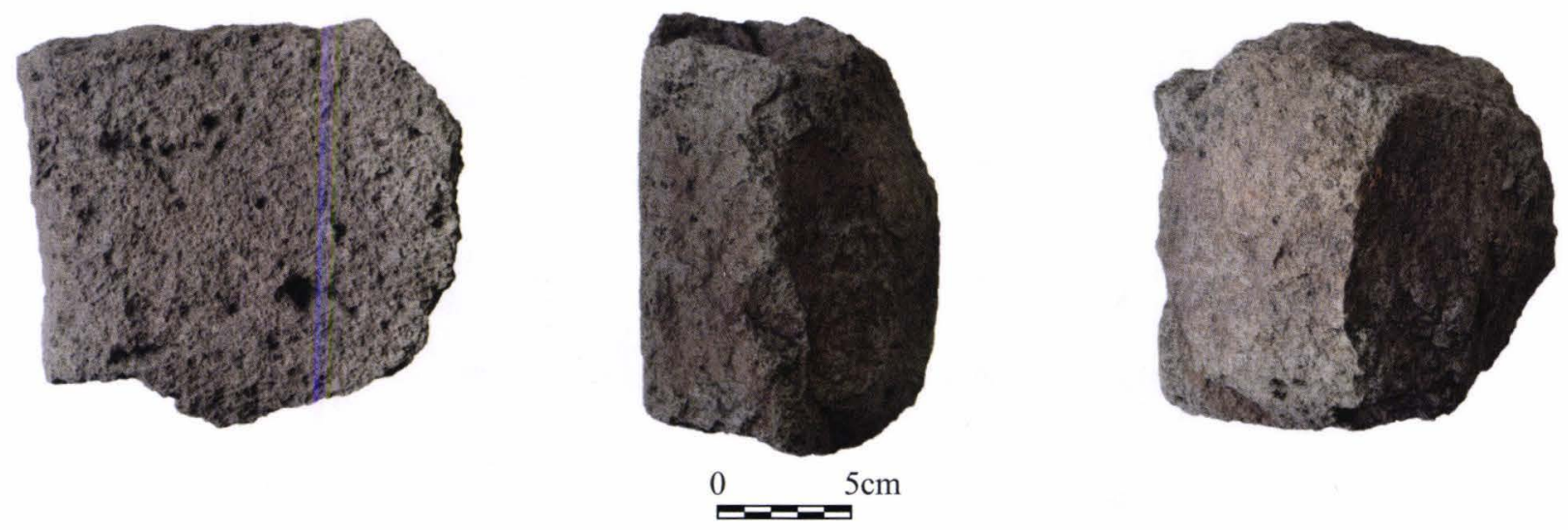

3.
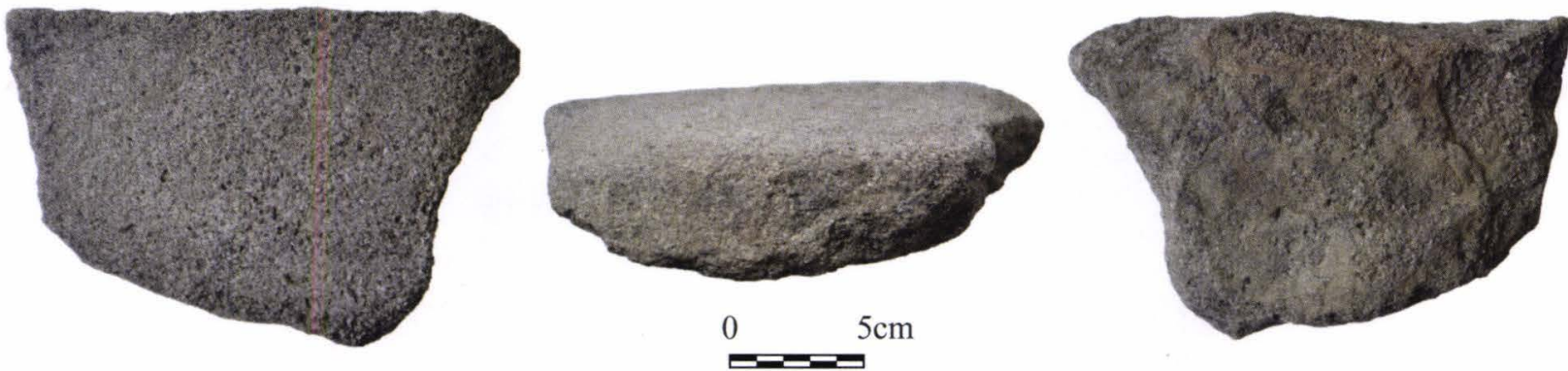

4.

Complexul 2, material litic: 1-3. Fragmente de râșniță; Complexul 4, material litic: 4. fragment de râşniţă 

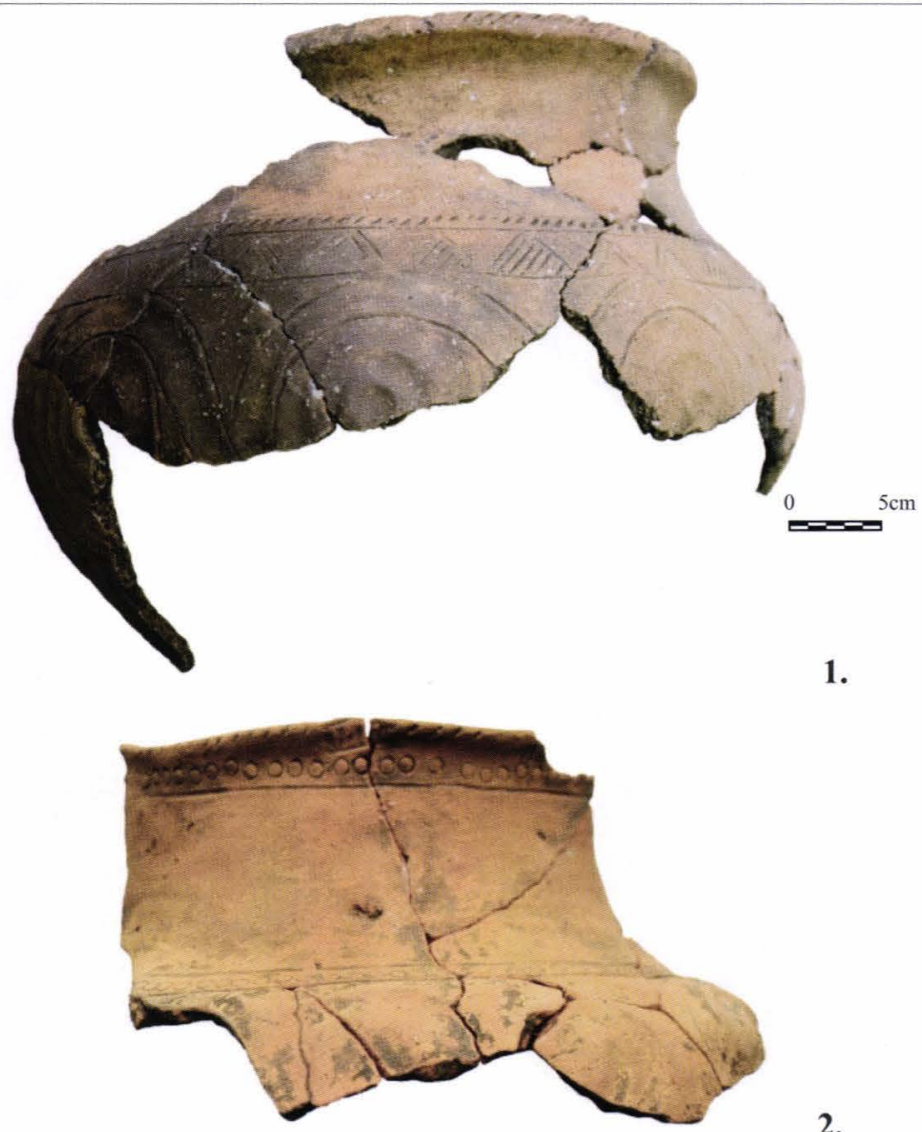

2.

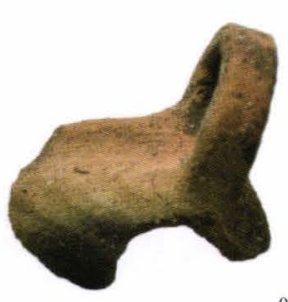

3.
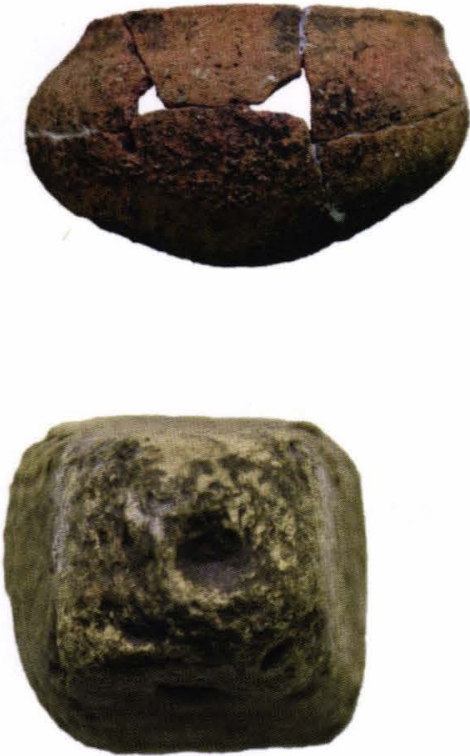

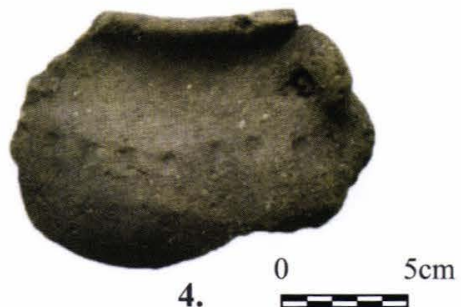

4. $=-5 \mathrm{c}$

5.

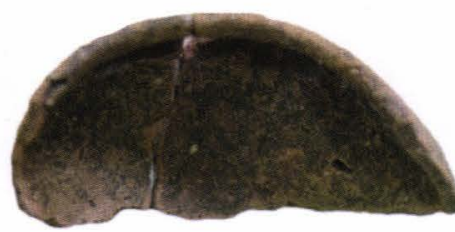

6.

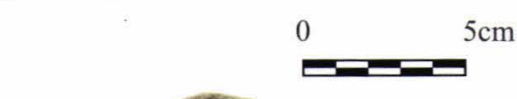

$5 \mathrm{~cm}$
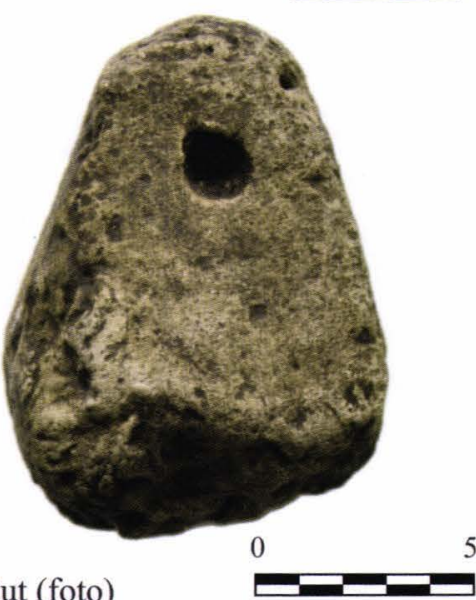

\section{PI. XVIII}




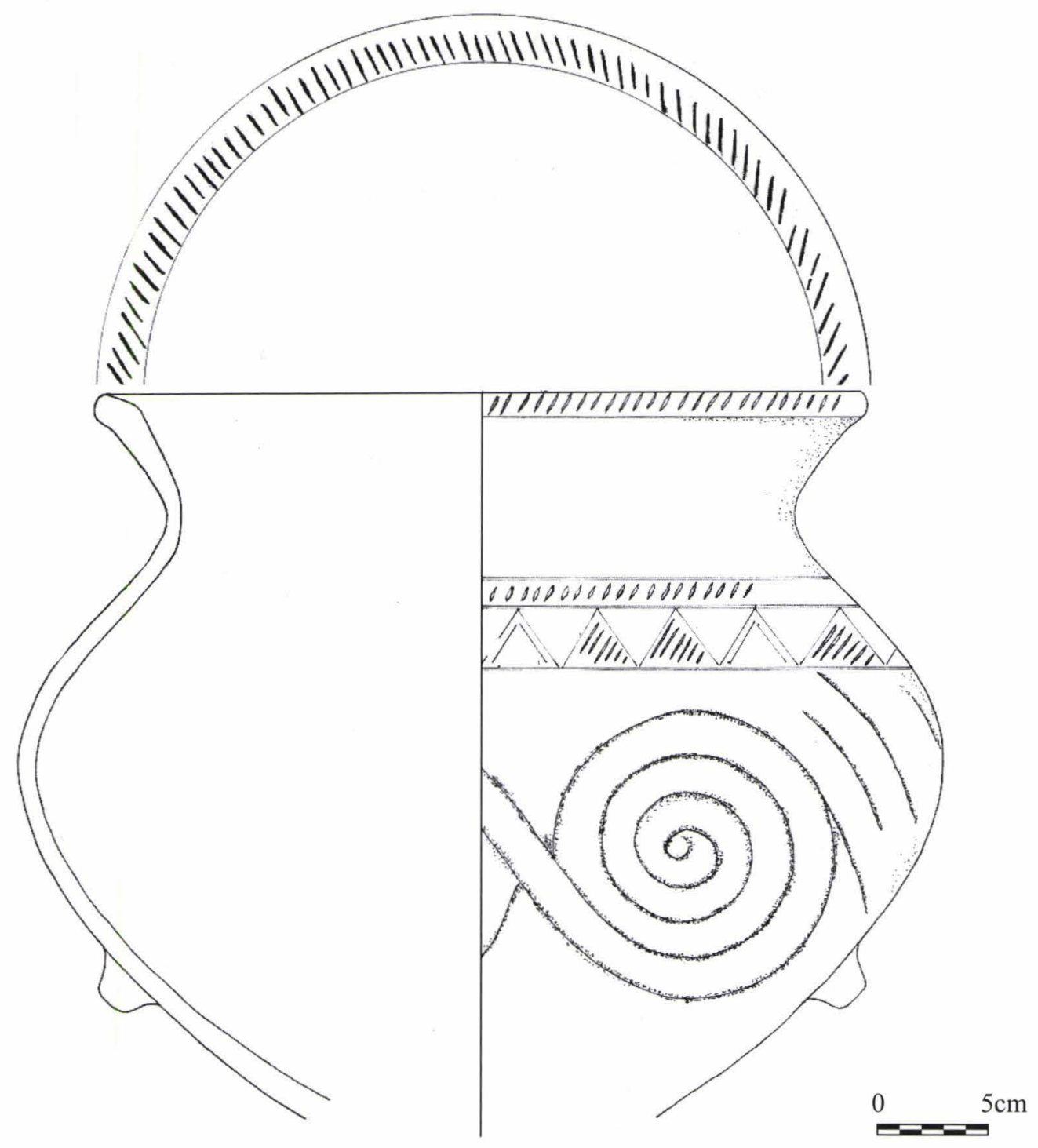

1.

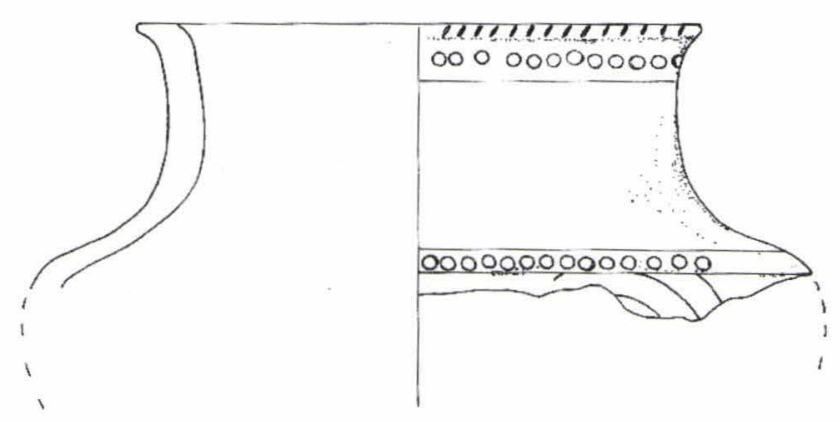

2.

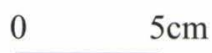

1-2. Oale din complexul 1

Pl. XIX 

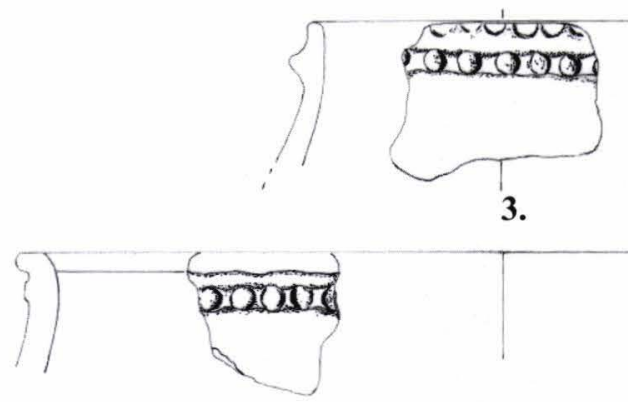

4.

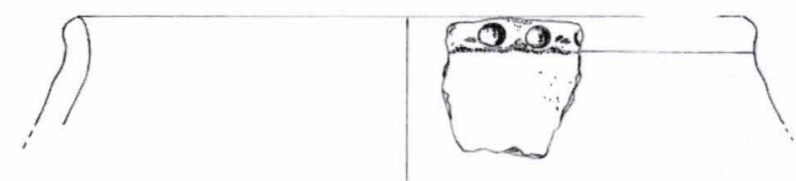

5.

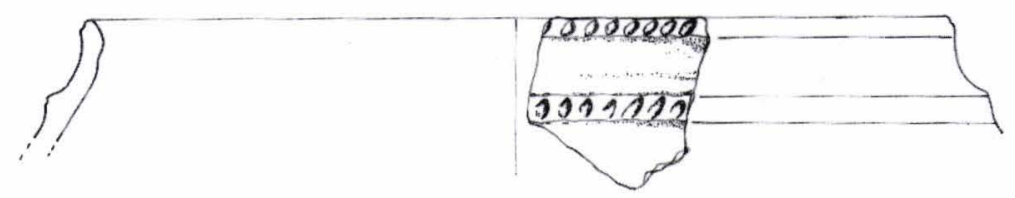

6.

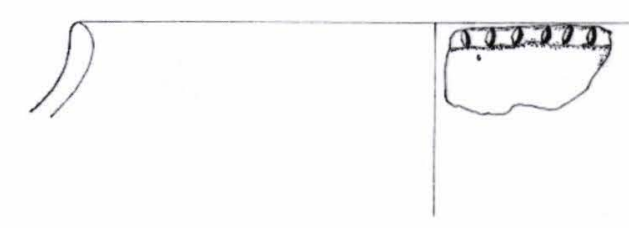

7.

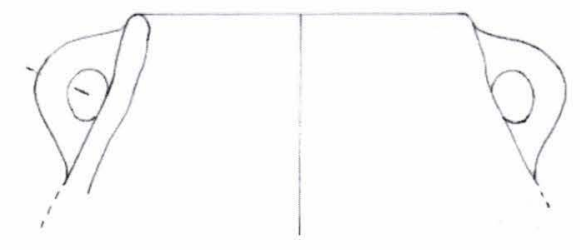

8.

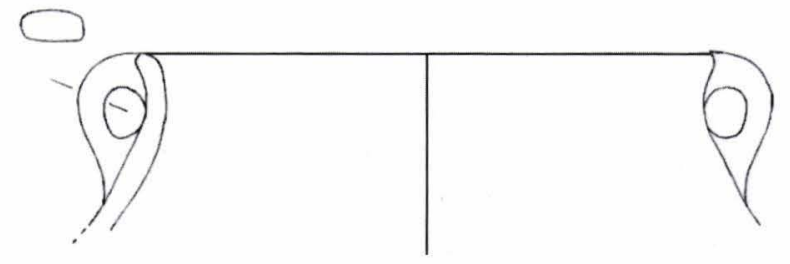

10.

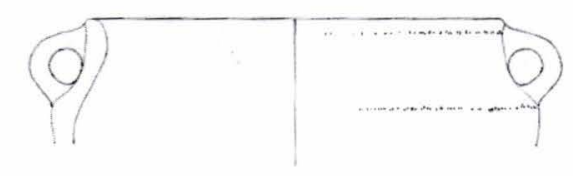

12.

3-12. Oale

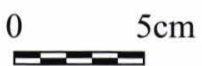




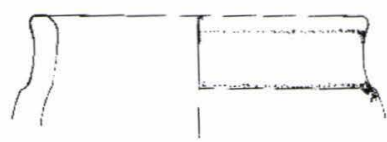

13.
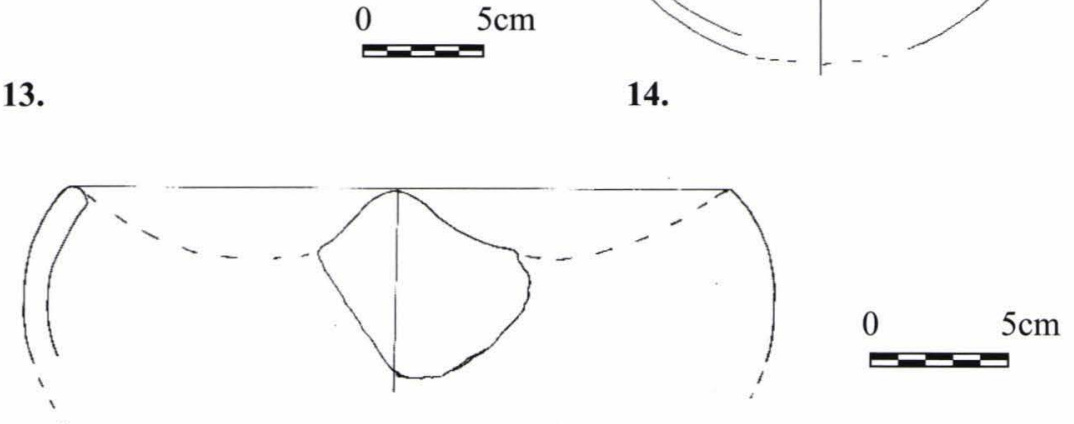

15.

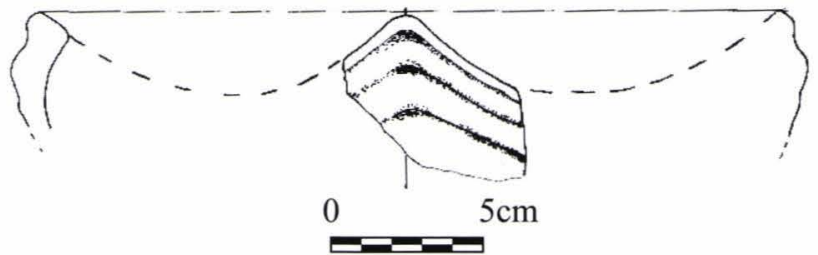

16.

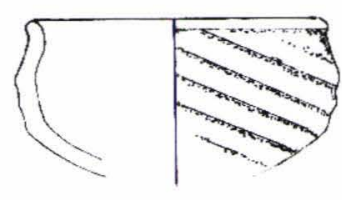

17.

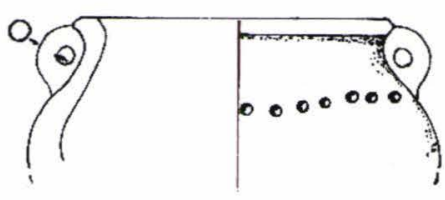

19.

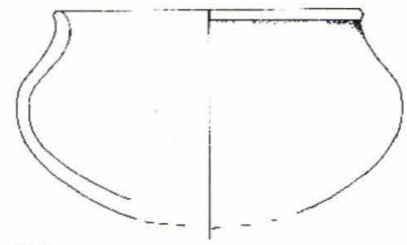

14.
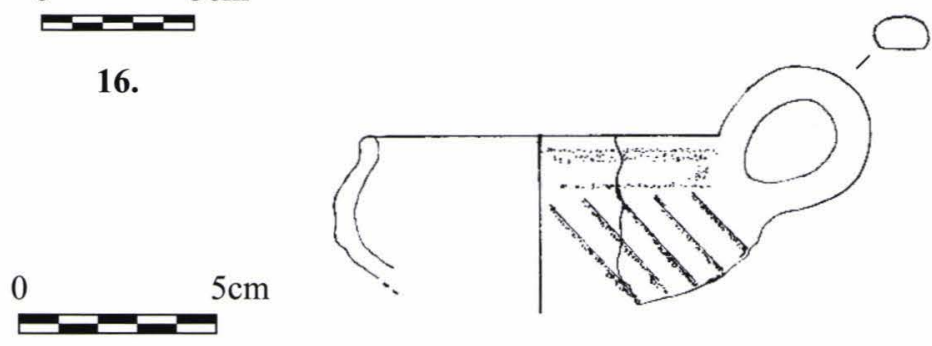

18.
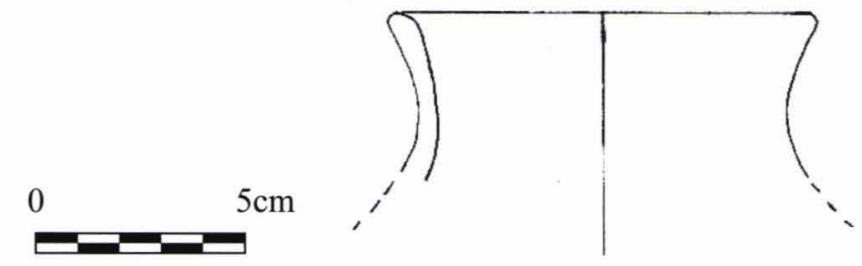

20.
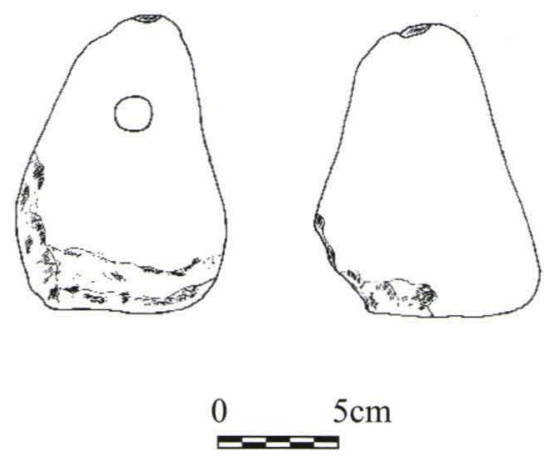

21.

13-14. Castroane; 15-16. Străchini; 17-18. Cești; 19. Vas miniatural; 20. Cană; 21. Greutate 
